\title{
Prognose arbeidsmarktinstroom van schoolverlaters per opleidingstype
}

Citation for published version (APA):

Berendsen, H., Dekker, R., de Grip, A., \& van de Loo, P. (1992). Prognose arbeidsmarktinstroom van schoolverlaters per opleidingstype. Researchcentrum voor Onderwijs en Arbeidsmarkt, Faculteit der Economische Wetenschappen. ROA Working Papers No. 2 https://doi.org/10.26481/umarow.1992002

Document status and date:

Published: 01/01/1992

DOI:

10.26481/umarow.1992002

Document Version:

Publisher's PDF, also known as Version of record

\section{Please check the document version of this publication:}

- A submitted manuscript is the version of the article upon submission and before peer-review. There can be important differences between the submitted version and the official published version of record.

People interested in the research are advised to contact the author for the final version of the publication, or visit the DOI to the publisher's website.

- The final author version and the galley proof are versions of the publication after peer review.

- The final published version features the final layout of the paper including the volume, issue and page numbers.

Link to publication

\footnotetext{
General rights rights.

- You may freely distribute the URL identifying the publication in the public portal. please follow below link for the End User Agreement:

www.umlib.nl/taverne-license

Take down policy

If you believe that this document breaches copyright please contact us at:

repository@maastrichtuniversity.nl

providing details and we will investigate your claim.
}

Copyright and moral rights for the publications made accessible in the public portal are retained by the authors and/or other copyright owners and it is a condition of accessing publications that users recognise and abide by the legal requirements associated with these

- Users may download and print one copy of any publication from the public portal for the purpose of private study or research.

- You may not further distribute the material or use it for any profit-making activity or commercial gain

If the publication is distributed under the terms of Article $25 \mathrm{fa}$ of the Dutch Copyright Act, indicated by the "Taverne" license above, 
PROGNOSE ARBEIDSMARKTINSTROOM VAN

SCHOOLVERLATERS PER OPLEIDINGSTYPE

ROA-W-1992/2

H. Berendsen, R.J.P. Dekker,

A. de Grip, P.J.E. van de Loo

RESEARCHCENTRUM VOOR ONDERWIJS EN ARBEIDSMARKT

Faculteit der Economische Wetenschappen

Rijksuniversiteit Limburg

Maastricht, maart 1992 
CIP-GEGEVENS KONINKLIJKE BIBLIOTHEEK, DEN HAAG

Prognose

Prognose arbeidsmarktinstroom van schoolverlaters per opleidingstype / $\mathrm{H}$. Berendsen... [et al.]. - Maastricht: Researchcentrum voor Onderwijs en Arbeidsmarkt, Faculteit der Economische Wetenschappen, Rijksuniversiteit Limburg. - (ROA-W-, ISSN 0922-4645; 1992/2)

Met lit. opg.

ISBN 90-5321-090-3 in spiraalband

Trefw.: onderwijs en arbeidsmarkt. 


\section{INHOUDSOPGAVE}

Bladzijde

VOORWOORD

1. INLEIDING

2. DE PROGNOSE VAN DE TOEKOMSTIGE UITSTROOM UIT HET REGULIER VOLTIJDONDERWIJS

2.1. Inleiding 6

2.2. Datamateriaal $\quad 6$

2.3. De prognose van het aantal schoolverlaters met een diploma van $\begin{array}{ll}\text { de laatstgevolgde voltijdopleiding } & 8\end{array}$

2.4. De prognose van het aantal schoolverlaters zonder diploma van $\begin{array}{ll}\text { de laatstgevolgde voltijdopleiding } & 10\end{array}$

2.5. De prognose van de totale uitstroom uit het regulier voltijdonderwijs per ROA-opleidingstype

3. DE PROGNOSE VAN DE GEDIPLOMEERDE UITSTROOM UIT HET REGULIER DEELTIJDONDERWIJS

3.1. Inleiding 15

3.2. Datamateriaal 15

3.3. De prognose van de gediplomeerde uitstroom uit het voltijd-

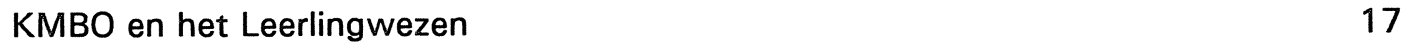

3.4. De prognose van de gediplomeerde uitstroom uit de eerste fase van het deeltijd-HBO

3.5. De prognose van de gediplomeerde uitstroom uit de tweede fase van het $\mathrm{HBO}$

3.6. De prognose van de gediplomeerde uitstroom uit de tweede fase lerarenopleiding van het WO

4. DE PROGNOSE VAN DE GEDIPLOMEERDE UITSTROOM UIT EEN AANTAL NIETREGULIERE OPLEIDINGEN

4.1. Inleiding $r$

4.2. Datamateriaal 23

4.3. De prognose van de gediplomeerde uitstroom uit het onderwijs in de openbare orde en veiligheid

4.4. De prognose van de gediplomeerde uitstroom uit het in-serviceonderwijs

4.5. De prognose van de gediplomeerde uitstroom uit enkele andere nietreguliere opleidingen 
5. DE PROGNOSE VAN DE GEDIPLOMEERDE UITSTROOM UIT HET BEROEPSGERICHTE VOLWASSENENONDERWIJS 31

5.1. Inleiding 31

5.2. Datamateriaal 31

5.3. De prognose van de gediplomeerde uitstroom uit het deeltijd-AVO, -LBO en -MBO

5.4. De prognose van de gediplomeerde uitstroom van de OU 36

5.5. De prognose van de gediplomeerde uitstroom uit het ESO en het BMO 37

5.6. De prognose van de gediplomeerde uitstroom uit bedrijfsopleidingen 38

5.7. De prognose van de gediplomeerde uitstroom uit het overige beroeps$\begin{array}{ll}\text { gerichte volwassenenonderwijs } & 39\end{array}$

$\begin{array}{ll}\text { 6. BESLUIT } & 43\end{array}$

$\begin{array}{ll}\text { LITERATUUR } & 45\end{array}$

BIJLAGE 1: ROA-OPLEIDINGSTYPEN

BIJLAGE 2: PROGNOSERESULTATEN 1989-1994 50 


\section{VOORWOORD}

In opdracht van het Ministerie van Onderwijs en Wetenschappen begon het Researchcentrum voor Onderwijs en Arbeidsmarkt (ROA) in 1986 aan de ontwikkeling van een informatiesysteem onderwijs-arbeidsmarkt. Inmiddels bevat dit systeem actuele arbeidsmarktgegevens, arbeidsmarktindicatoren en arbeidsmarktprognoses voor circa 90 beroepsklassen en 50 opleidingstypen. Over de modellen die bij het opstellen van de arbeidsvraagprognoses (de verwachte uitbreidingsvraag en de toekomstige vervangingsvraag per beroepsklasse en per opleidingstype) worden gehanteerd zijn reeds een aantal publikaties verschenen. Van de ramingsmethodiek met betrekking tot het toekomstig arbeidsaanbod bestond echter nog geen uitvoerige beschrijving. Met dit werkdocument wordt getracht in deze lacune te voorzien.

De hier beschreven methodiek betreft de prognose van de arbeidsmarktinstroom van schoolverlaters per opleidingstype in de derde volledige versie van het ROA-informatiesysteem, waarvan de resultaten zijn gepresenteerd in het rapport De arbeidsmarkt naar opleiding en beroep tot 1994 (Researchcentrum voor Onderwijs en Arbeidsmarkt, 1992a) en de bijbehorende Statistische bijlage (Researchcentrum voor Onderwijs en Arbeidsmarkt, 1992b). Bij deze prognose wordt niet alleen rekening gehouden met de instroom op de arbeidsmarkt van schoolverlaters van het regulier voltijdonderwijs, maar ook met de uitstroom uit het regulier deeltijdonderwijs, een aantal niet-reguliere opleidingen en de beroepsgerichte volwasseneneducatie.

De prognosemethodiek werd, onder leiding van dr. A. de Grip, ontwikkeld door drs. $H$. Berendsen, drs. R.J.P. Dekker en drs. P.J.E. van de Loo. P.W.T. Ghijssen en M.E.C. Reiners assisteerden bij de dataverwerking. 


\section{INLEIDING}

In opdracht van het Ministerie van Onderwijs en Wetenschappen (O\&W) heeft het Researchcentrum voor Onderwijs en Arbeidsmarkt (ROA) een informatiesysteem onderwijs-arbeidsmarkt ontwikkeld waaruit gegevens kunnen worden geput ten behoeve van de studie- en beroepskeuzevoorlichting aan leerlingen en studenten in het voortgezet en het hoger onderwijs. Daarnaast bevat het systeem informatie die kan worden gebruikt voor met name het onderwijs- en het arbeidsvoorzieningsbeleid. De informatie heeft niet alleen betrekking op de actuele arbeidsmarktsituatie, maar ook op de verwachte toekomstige arbeidsmarktsituatie. Zo bevat het systeem prognoses van de werkgelegenheidsontwikkeling (de uitbreidingsvraag) en de vervangingsbehoefte per beroepsklasse en per opleidingstype.

Een belangrijk element in het prognosegedeelte van het ROA-informatiesysteem wordt gevormd door de voor elk van de onderscheiden opleidingscategorieën verstrekte informatie over de vooruitzichten voor toekomstige nieuwkomers op de arbeidsmarkt. Per opleidingstype wordt een indicatie gegeven van de verwachte toekomstige arbeidsmarktsituatie, door de prognoses van de uitbreidingsvraag en de vervangingsvraag, die tezamen de totale arbeidsvraag vormen, te confronteren met de prognoses van het te verwachten aanbod. Dit te verwachten aanbod omvat enerzijds de werkenden die zich ook in de prognoseperiode blijven aanbieden op de arbeidsmarkt en de verwachte uitstroom uit het werklozenbestand aan het begin van de prognoseperiode en anderzijds de instroom van schoolverlaters ${ }^{1}$ op de arbeidsmarkt. De waarde van de indicator die op basis van de verhouding tussen vraag en aanbod kan worden berekend, wordt uiteindelijk vertaald in een kwalitatieve typering van het arbeidsmarktperspectief voor schoolverlaters in de desbetreffende opleidingscategorie.

Reeds eerder verschenen publikaties over de prognosemodellen met betrekking tot de uitbreidingsvraag per beroepsklasse (Dekker, De Grip en Heijke, 1988 en 1990) en de uitbreidingsvraag per opleidingstype (Beekman, Dekker, De Grip en Heijke, 1989 en 1991) alsmede over de verdere ontwikkeling van beide prognosemodellen (Peeters, 1990). Ook is reeds eerder verslag gedaan over de wijze waarop de prognose van de toekomstige vervangingsvraag wordt bepaald (Willems en De Grip, 1990). In dit werkdocument zal een uiteenzetting worden gegeven van de methodiek die wordt gebruikt om voor de diverse in het informatiesysteem onderscheiden opleidingstypen een raming te maken van het aantal schoolverlaters dat in de prognoseperiode zal uitstromen naar de arbeidsmarkt ${ }^{2}$. De uitkomsten van deze prognose zijn gebruikt voor de

1. Schoolverlaters zijn alle personen die in een bepaald jaar voltijdonderwijs volgen en gedurende het onmiddellijk volgende schooljaar geen voltijdonderwijs meer genieten. Daarbij worden tevens de gevolgen van de om- en bijscholing in het kader van het deeltijdonderwijs voor het aanbod naar opleidingstype verdisconteerd.

2. In Berendsen, De Grip, Wieling en Willems (1992) wordt nader ingegaan op de methodiek die gehanteerd is om in aansluiting op deze landelijke prognoses van de instroom van schoolverlaters op de arbeidsmarkt ook regionale (provinciale) prognoses van het aanbod van schoolverlaters op te stellen. 
derde volledige versie van het ROA-informatiesysteem onderwijs-arbeidsmarkt, die ten grondslag ligt aan de samenstelling van de arbeidsmarktmodule van het geautomatiseerde studie- en beroepskeuzevoorlichtingssysteem I-See! (Information System on Education and Employment) van het Landelijk Dienstverlenend Centrum voor Studie- en Beroepskeuzevoorlichting (LDC). Daarnaast vormen de ramingsuitkomsten éen van de bouwstenen voor het rapport De arbeidsmarkt naar opleiding en beroep tot 1994 (Researchcentrum voor Onderwijs en Arbeidsmarkt, 1992a) en de bijbehorende Statistische bijlage (Researchcentrum voor Onderwijs en Arbeidsmarkt, 1992b).

In de derde volledige versie van het ROA-informatiesysteem worden 54 opleidingscategorieën onderscheiden (zie bijlage 1). Daaronder bevinden zich 5 restcategorieën. In totaal zijn er derhalve voor 49 opleidingstypen arbeidsmarktprognoses opgesteld. Bij het ramen van de instroom van schoolverlaters op de arbeidsmarkt voor elk opleidingstype wordt aangesloten bij de wijze waarop de onderwijskwalificaties van beroepsbeoefenaren in de Arbeidskrachtentelling (AKT) en de Enquête Beroepsbevolking (EBB) van het Centraal voor de Statistiek (CBS) worden gecodeerd. Dit is noodzakelijk om de prognose van de verwachte arbeidsvraag en de raming van het toekomstige aanbod op elkaar af te stemmen. In dit opzicht zijn met name de volgende drie punten van belang:

- in de AKT en de EBB wordt de hoogst behaalde onderwijskwalificatie van een individu geregistreerd;

- de opleiding van een individu wordt geclassificeerd op basis van de Standaard Onderwijsindeling (SOI) van het CBS;

- van een individu worden niet alleen de in het voltijdonderwijs verkregen opleidingskwalificaties gemeten, maar ook de in het deeltijdonderwijs verworven kwalificaties.

De methodiek voor de raming van het toekomstig aanbod van schoolverlaters op de arbeidsmarkt steunt in belangrijke mate op externe prognoses. Aan de prognoses liggen, evenals aan de onderliggende externe prognoses, geen verklarende modellen ten grondslag. Het rekenmodel wordt gekenmerkt door een stapsgewijze modulaire opbouw, die in figuur 1.1. schematisch is weergegeven. Globaal gesproken kan daarbij een tweetal stappen worden onderscheiden ${ }^{3}$. In de eerste stap wordt een prognose gemaakt van de uitstroom uit het regulier voltijdonderwijs ${ }^{4}$, waarbij ook het universitair deeltijdonderwijs (met uitzondering van de Open Universiteit) wordt inbegrepen, terwijl het Kort Middelbaar Beroepsonderwijs (KMBO) in voltijdse vorm buiten beschouwing blijft. De uitstroom uit het regulier voltijdonderwijs bestaat uit schoolverlaters die

3. Verderop zal nader worden ingegaan op de verschillende stappen binnen deze hoofdindeling.

4. Het regulier voltijd- en deeltijdonderwijs betreft het gehele door de Ministeries van Onderwijs en Wetenschappen en Landbouw, Natuurbeheer en Visserij gefinancierde onderwijs, met uitzondering van de zelfstandige theologische hogescholen en enige gebudgetteerde onderwijssoorten in het voortgezet onderwijs in deeltijdse vorm (basiseducatie, primaire beroepsgerichte volwasseneneducatie, cursorisch ondernemersonderwijs en specifieke cursussen in het kader van het beroepsonderwijs aan volwassenen). 
Figuur 1.1. Globaal schema van de methodiek ter raming van de toekomstige instroom van schoolverlaters op de arbeidsmarkt naar ROA-opleidingstype

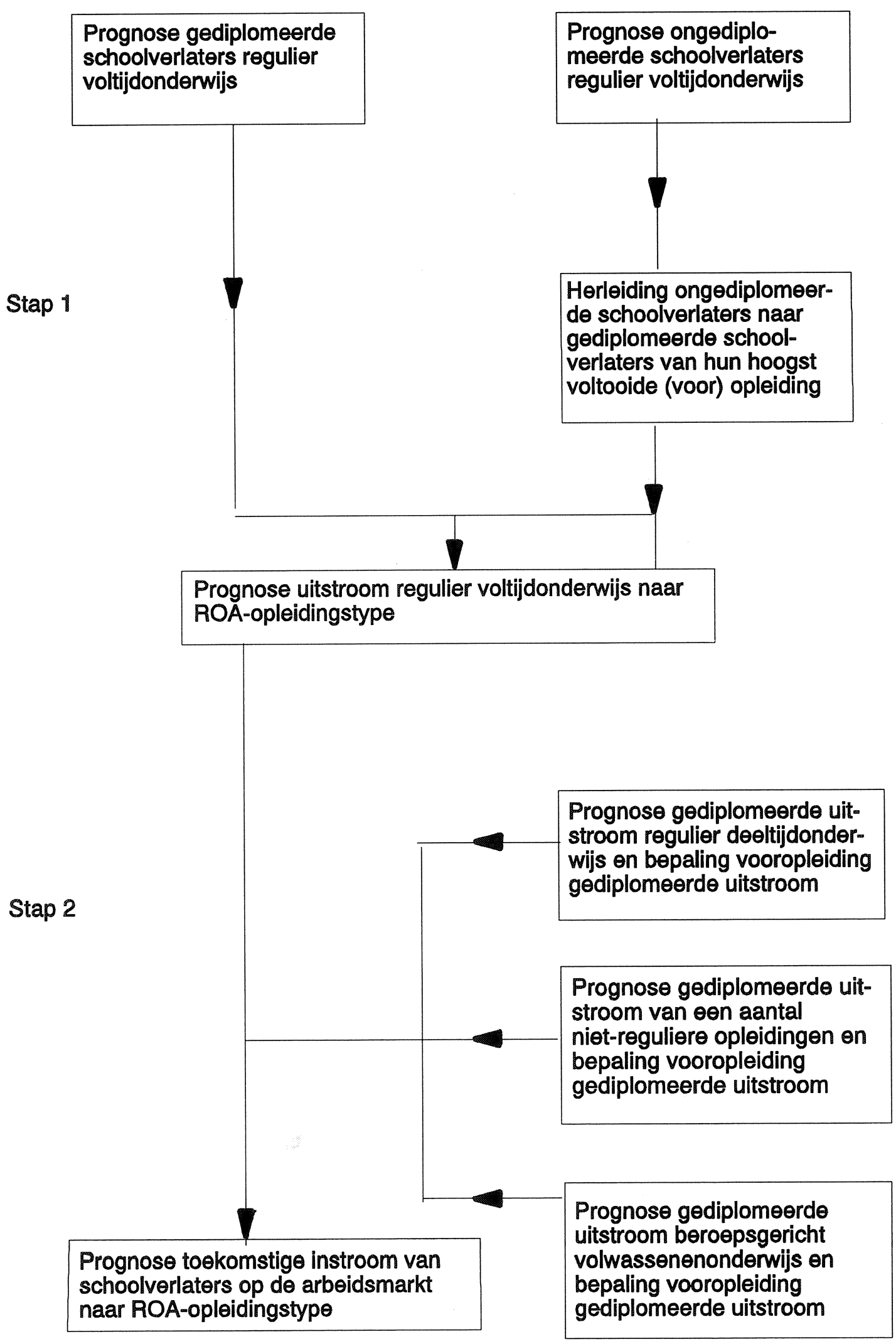


de het laatst door hen gevolgde voltijdopleiding met een diploma hebben afgerond en schoolverlaters die de laatstgevolgde voltijdopleiding ongediplomeerd vaarwel hebben gezegd. Daar in de AKT en de EBB de hoogst behaalde onderwijskwalificatie van een individu wordt gemeten, moeten de schoolverlaters zonder diploma van het laatstgevolgde voltijdonderwijs worden herleid tot gediplomeerde schoolverlaters van hun hoogst voltooide vooropleiding ${ }^{5}$. Vervolgens worden zij opgeteld bij de schoolverlaters voor wie de overeenkomstige laatstgevolgde voltijdopleiding tevens de hoogst voltooide voltijdopleiding is. Aldus wordt een prognose verkregen van de uitstroom uit het regulier voltijdonderwijs naar ROA-opleidingstype.

Met de prognose van de uitstroom uit het regulier voltijdonderwijs ligt de totale toekomstige instroom van schoolverlaters op de arbeidsmarkt vast. Degenen die uitstromen uit het regulier voltijdonderwijs kunnen echter doorstromen naar een vorm van niet-regulier voltijdonderwijs of naar een deeltijdopleiding. Wanneer iemand een deeltijdopleiding of een niet-reguliere voltijdopleiding met een diploma afsluit en de gevolgde opleiding ligt op een hoger niveau dan de genoten vooropleiding, vermindert het (potentiële) aanbod in de opleidingscategorie waartoe de vooropleiding behoort, terwijl het aanbod in de categorie waartoe de deeltijdopleiding of de nietreguliere voltijdopleiding wordt gerekend, toeneemt. Om met dit gegeven rekening te houden, vindt in de tweede stap van de aanbodraming een herverdeling plaats van de uitstroom uit het regulier voltijdonderwijs op basis van een prognose van de gediplomeerde uitstroom uit het regulier deeltijdonderwijs (inclusief het voltijd-KMBO), een aantal niet-reguliere opleidingen en het beroepsgerichte volwassenenonderwijs ${ }^{6}$. Daarbij wordt tevens de vooropleiding van de gediplomeerde uitstroom uit de bovengenoemde onderwijssoorten bepaald, omdat er zoals gezegd alleen wordt gesproken van een veranderd kwalificatieprofiel als de behaalde opleidingskwalificatie hoger is dan de gevolgde vooropleiding. Na deze herverdeling van de uitstroom uit het regulier voltijdonderwijs resulteert de gewenste prognose van de toekomstige instroom van schoolverlaters op de arbeidsmarkt naar ROA-opleidingstype.

In de derde volledige versie van het ROA-informatiesysteem loopt de prognoseperiode van 1989 tot 1994. Derhalve is een raming opgesteld van de toekomstige instroom van schoolverlaters op de arbeidsmarkt in de studiejaren 1988/'89 tot en met 1992/'93. Dit zijn dus vijf studiejaren. Schoolverlaters uit de studiejaren 1987/' 88 en 1993/'94 worden niet meegerekend. De eersten kwamen immers reeds voor 1989 op de arbeidsmarkt, terwijl de laatsten doorgaans pas in de tweede helft van het studiejaar 1993/'94 instromen op de arbeidsmarkt. Strikt genomen zouden de leerlingen die het studiejaar 1993/'94 reeds in 1993 verlaten eigenlijk wel in de prognose van de instroom op de arbeidsmarkt moeten worden betrokken, terwijl de leerlingen die al in 1988 afscheid namen van het studiejaar 1988/'89 juist niet zouden moeten worden meegeteld. Het exacte tijdstip waarop schoolverlaters op de arbeidsmarkt instromen is evenwel niet

5. Degenen die geen enkel diploma hebben behaald worden herleid tot schoolverlaters van het basisonderwijs.

6. Het regulier volwassenenonderwijs maakt weliswaar deel uit van het regulier deeltijdonderwijs, maar in dit werkdocument wordt het ten behoeve van de overzichtelijkheid samengevoegd met het niet-reguliere volwassenenonderwijs. 
bekend. Daarom wordt er van uit gegaan, dat schoolverlaters niet voor het einde van het studiejaar instromen op de arbeidsmarkt ${ }^{7}$.

Bij de prognose van de werkgelegenheidsvooruitzichten voor nieuwkomers op de arbeidsmarkt wordt, zoals reeds eerder werd opgemerkt, ook rekening gehouden met de werkloosheid aan het begin van de prognoseperiode. Daartoe wordt gebruik gemaakt van de aantallen werklozen op 15 april 1989. Onder deze aantallen bevinden zich wel de werkzoekende schoolverlaters uit het studiejaar 1987/'88, maar de schoolverlaters die in (mei of juni van) het studiejaar 1988/'89 examen deden, waren op 15 april 1989 nog niet beschikbaar voor de arbeidsmarkt en werden op die datum, ook al zouden ze reeds staan ingeschreven als werkzoekende, nog niet tot de werklozen gerekend. Afgezien van de leerlingen die het onderwijs voor het einde van het studiejaar 1988/'89 verlieten en zich als werkzoekende bij het arbeidsbureau meldden, vinden er dus geen dubbeltellingen van schoolverlaters uit het studiejaar 1988/' 89 plaats.

De verdere opzet van dit werkdocument is als volgt. In hoofdstuk 2 wordt beschreven hoe de raming van de toekomstige uitstroom uit het regulier voltijdonderwijs naar ROA-opleidingstype tot stand is gekomen (stap 1 in figuur 1.1.). De diverse onderdelen van stap 2 uit figuur 1.1. worden besproken in de hoofdstukken 3, 4 en 5 . In hoofdstuk 3 wordt ingegaan op de wijze waarop een prognose van de gediplomeerde uitstroom uit het regulier deeltijdonderwijs is gemaakt. De prognose van de gediplomeerde uitstroom uit een aantal niet-reguliere opleidingen komt in hoofdstuk 4 aan de orde. In hoofdstuk 5 wordt aangegeven op welke wijze een prognose van de gediplomeerde uitstroom uit het beroepsgerichte volwassenenonderwijs is gemaakt. Tot besluit worden in hoofdstuk 6 enige kanttekeningen geplaatst bij de huidige ramingsmethodiek. Tevens wordt aangegeven in welke richting eventuele verbeteringen mogelijk zijn.

7. In principe zal de mogelijke vertekening die hierdoor optreedt zeer gering zijn, temeer doordat de aan het eind van de prognoseperiode niet meegetelde instroom weg valt tegen de aan het begin van de prognoseperiode wel meegetelde instroom, die in feite reeds in 1988 op de arbeidsmarkt is ingestroomd. 


\section{DE PROGNOSE VAN DE TOEKOMSTIGE UITSTROOM UIT HET REGULIER VOLTIJDONDERWIJS}

\subsection{Inleiding}

Het toekomstig aanbod van schoolverlaters op de arbeidsmarkt wordt in belangrijke mate bepaald door de uitstroom uit het regulier voltijdonderwijs. Strikt genomen impliceert het uitstromen uit het voltijdonderwijs weliswaar niet automatisch dat men instroomt op de arbeidsmarkt, maar de participatiegraad van personen onder de 25 jaar die geen voltijdonderwijs meer volgen, is dusdanig hoog (zie Manders, 1989), dat de instroom op de arbeidsmarkt gelijk wordt gesteld aan de uitstroom uit het voltijdonderwijs. De raming van de toekomstige uitstroom uit het regulier voltijdonderwijs vormt dan ook het startpunt van de ROA-prognoses van het toekomstig aanbod van schoolverlaters op de arbeidsmarkt ${ }^{8}$.

De uitstroom uit het regulier voltijdonderwijs bestaat uit twee componenten: schoolverlaters die de laatstgevolgde voltijdopleiding met een diploma hebben afgerond en schoolverlaters die de laatstgevolgde voltijdopleiding zonder diploma hebben beëindigd. De raming van het te verwachten aantal schoolverlaters dat de laatstgevolgde voltijdopleiding met een diploma afsluit, wordt beschreven in paragraaf 2.3. In paragraaf 2.4. wordt ingegaan op de prognose van het aantal schoolverlaters dat de laatstgevolgde voltijdopleiding ongediplomeerd heeft beëindigd. Tevens wordt in deze paragraaf uiteengezet op welke wijze deze schoolverlaters zijn herleid naar schoolverlaters van de vooropleiding die ze wel met een diploma hebben afgesloten ${ }^{9}$. Tot slot volgt in paragraaf 2.5 . de beschrijving van de wijze waarop de prognose van de toekomstige uitstroom uit het regulier voltijdonderwijs naar de in het informatiesysteem onderwijs-arbeidsmarkt onderscheiden ROA-opleidingstypen is versleuteld. Voorafgaand aan de beschrijving van de ramingsmethodiek zal in paragraaf 2.2 . echter eerst een overzicht van het gebruikte datamateriaal worden gegeven.

\subsection{Datamateriaal}

Bij de raming van de toekomstige uitstroom uit het regulier voltijdonderwijs is gebruik gemaakt van de volgende databronnen:

1. de tijdreeksen uit de SKILL-onderwijsprognose (jaargang 1990, versie II) van het Ministerie

8. Het gebruikte model is gebaseerd op vaste uitstroomcoëfficiënten. In het Verenigd Koninkrijk is reeds een analytisch model ontwikkeld, waarin de beslissing van jongeren om al dan niet verder te leren door een aantal onafhankelijke variabelen wordt verklaard (zie Whitfield en Wilson, 1991). Ook in de Verenigde Staten is onderzoek op dit terrein gedaan (zie bijvoorbeeld Mattila, 1982). In Nederland is door het Centraal Planbureau getracht een analysemodel van de vraag naar onderwijs te construeren (zie Kuhry, 1986). Een dergelijk verklarend model is echter tot op heden in Nederland niet toegepast.

9. Vanwege de afstemming op de prognose van de totale vraag naar nieuwkomers op de arbeidsmarkt moet immers de hoogst verworven onderwijskwalificatie worden bepaald. 
van Onderwijs en Wetenschappen (Ministerie van Onderwijs en Wetenschappen, 1990);

2. de onderwijsmatrix 1989 van het CBS;

3. de Integrale Leerlingtelling (ILT) 1990/'91 van het Ministerie van Onderwijs en Wetenschappen;

4. de Statistiek van het lager beroepsonderwijs 1989/'90 (Centraal Bureau voor de Statistiek, 1990b);

5. de Statistiek van het middelbaar beroepsonderwijs 1989/'90 (Centraal Bureau voor de Statistiek, 1990c);

6. werktabellen die het CBS gebruikt bij de opstelling van de onderwijsmatrix;

7. de WORSA (Wetenschappelijk Onderwijs Raming Studenten Aantallen)-raming 1990 van de Taakgroep Studentenramingen (Taakgroep Studentenramingen, 1990a).

De tijdreeksen uit de SKILL-onderwijsprognose vormen de basis van de ROA-prognose van de uitstroom uit het regulier voltijdonderwijs ${ }^{10}$. De SKILL-prognoses geven een integrale raming van de leerlingenaantallen in het regulier voltijdonderwijs, de aantallen behaalde diploma's en de aantallen schoolverlaters. De prognoses zijn gedifferentieerd naar geslacht en in sommige gevallen ook naar leeftijd. De ramingsprocedure steunt op de onderwijsmatrices van het CBS. De prognoseperiode eindigt in het studiejaar 2010/'11. De ROA-prognose van de uitstroom uit het regulier voltijdonderwijs is gebaseerd op de ramingen van de aantallen gediplomeerden naar richting en de schoolverlaters naar schoolsoort en diplomabezit.

Naast de SKILL-prognoses vormt ook de onderwijsmatrix van het CBS een belangrijke databron voor de aanbodramingen van het ROA. De onderwijsmatrix heeft betrekking op het regulier voltijdonderwijs en geeft de in-, door- en uitstroom in twee opeenvolgende schooljaren weer. Typerend voor de matrixtabel is, dat niet alleen een overzicht wordt verkregen van de aantallen in een bepaald schooljaar ingeschreven leerlingen, maar ook inzicht wordt gegeven in de doorstroom naar andere leerjaren of schoolsoorten. Met betrekking tot de ingeschreven leerlingen in het voorafgaande jaar wordt tevens onderscheid gemaakt tussen personen die aan het eind van dat jaar een diploma hebben behaald en leerlingen die het desbetreffende jaar zonder diploma hebben afgesloten. In de derde volledige versie van het ROA-informatiesysteem is gebruik gemaakt van de door het CBS ter beschikking gestelde onderwijsmatrix 1989. Dit is de meest recente onderwijsmatrix. Voor de opstelling van de SKILL-prognoses zijn echter oudere onderwijsmatrices gebruikt. Consequentie hiervan is dat de ROA-prognoses niet binnen de SKILL-randtotalen blijven. De reden dat desondanks gebruik is gemaakt van de meest recente onderwijsmatrix is dat leerlingen in toenemende mate doorstromen naar een (hogere) vervolgopleiding in het regulier voltijdonderwijs. Daardoor stromen zij later uit naar de arbeidsmarkt. Bij het opstellen van de prognoses zou het gebruik van oudere onderwijsmatrices derhalve met name tot een overschatting van de arbeidsmarktinstroom van lager opgeleiden kunnen leiden.

10. De SKILL-raming is inmiddels opgevolgd door de Referentieraming (Ministerie van Onderwijs en Wetenschappen, 1991). Het tijdstip waarop de uitkomsten van deze raming beschikbaar kwamen, maakte het voor het ROA echter onmogelijk om hiervan op verantwoorde wijze gebruik te maken. Vandaar dat voor de prognoses in de derde versie van het ROA-informatiesysteem opnieuw de SKILL-ramingen 1990 als basis zijn genomen. 
De Integrale Leerlingtelling is een telling van het aantal leerlingen en geslaagden in het voortgezet (voltijd)onderwijs voorzover dat door het Ministerie van Onderwijs en Wetenschappen wordt gefinancierd"1 ${ }^{11}$ De tellingen zijn uitgesplitst naar school, onderwijselement (middelbaar algemeen voortgezet onderwijs, hoger algemeen voortgezet onderwijs, atheneum, gymnasium, lager technisch onderwijs/richting timmeren, lager huishoudelijk en nijverheidsonderwijs/richting huishoudkunde, middelbaar economisch en administratief onderwijs/commerciële richting, etc.), leerjaar en geslacht. Het aggregatieniveau is dus zeer laag.

Voor de prognose van de uitstroom uit het lager en middelbaar agrarisch onderwijs is gebruik gemaakt van twee andere databronnen: de Statistiek van het lager beroepsonderwijs en de Statistiek van het middelbaar beroepsonderwijs. De genoemde statistieken bevatten feitelijke informatie over leerlingenaantallen, aantallen geslaagden, etc. Verder kon voor de uitstroomraming met betrekking tot het hoger beroepsonderwijs (HBO) worden beschikt over de werktabellen die het CBS vervaardigt ten behoeve van de opstelling van de onderwijsmatrix. Deze tabellen hebben betrekking op het studiejaar 1989/'90 en geven informatie over de aantallen studenten in de eerste en tweede fase van het $\mathrm{HBO}$, alsmede over aantallen geslaagden.

De laatste gegevensbron voor de prognose van de uitstroom uit het regulier voltijdonderwijs wordt gevormd door deel I van de HO-raming 1990: de zogenaamde WORSA-raming. De WORSA-raming wordt sinds 1975 uitgebracht en heeft betrekking op (toekomstige) aantallen eerstejaars-studenten, ingeschrevenen en afgestudeerden per studierichting en instelling in het wetenschappelijk onderwijs. De ramingen zijn geslachtsspecifiek. Tweede fase opleidingen worden niet meegenomen in de raming.

2.3. De prognose van het aantal schoolverlaters met een diploma van de laatstgevolgde voltijdopleiding

Voor de raming van het te verwachten aantal schoolverlaters dat de laatstgevolgde voltijdopleiding met een diploma afsluit, wordt uitgegaan van de aantallen gediplomeerden naar richting uit de SKILL-ramingen. Door per richting de aantallen gediplomeerden te sommeren over de studiejaren 1988/'89-1992/'93, wordt een prognose verkregen van het totaal aantal gediplomeerden in de prognoseperiode. Om een raming van het aantal gediplomeerde schoolverlaters te krijgen, zal moeten worden bepaald welk deel van de gediplomeerden geen vervolgopleiding in het voltijdonderwijs gaat volgen. Daartoe wordt gebruik gemaakt van de onderwijsmatrix 1989. Hieruit kan per schoolsoort een uitstroompercentage worden berekend door het aantal gediplomeerde uitstromers te delen door het totaal aantal gediplomeerden aan het einde van het voorafgaande schooljaar. Van dit uitstroompercentage wordt verondersteld, dat het gedurende de rest van de prognoseperiode constant blijft.

11. De ILT bevat geen gegevens over het lager en middelbaar agrarisch onderwijs, omdat dit door het Ministerie van Landbouw, Natuurbeheer en Visserij wordt gefinancierd. 
$-9-$

Figuur 2.1. Methodiek ter raming van het toekomstig aantal schoolverlaters met een diploma van de laatstgevolgde voltijdopleiding

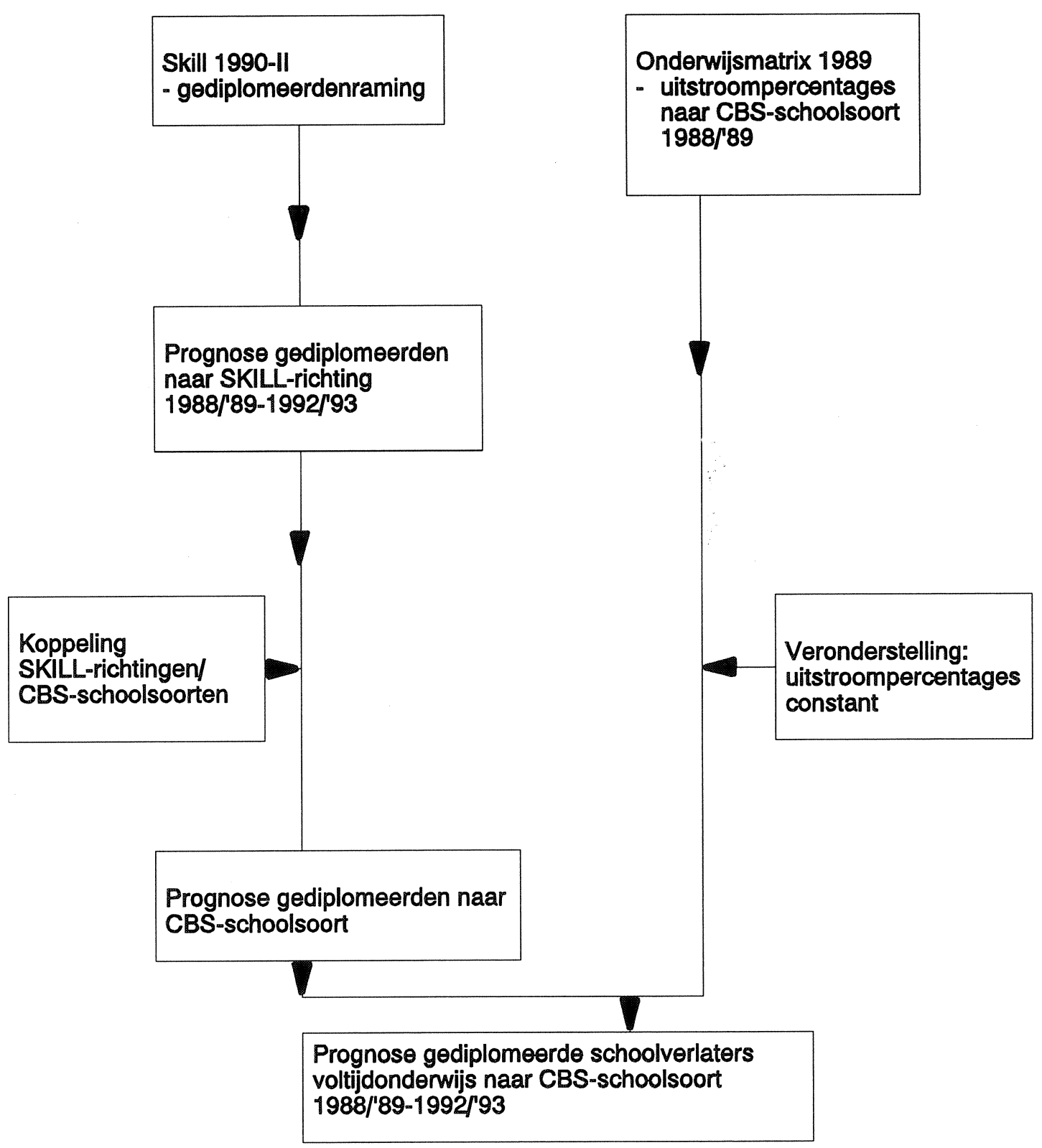


$\mathrm{Na}$ aggregatie van de 39 SKILL-richtingen ${ }^{12}$ tot 23 van de in totaal 27 schoolsoorten die het CBS in de onderwijsmatrix onderscheidt ${ }^{13}$, resulteert vermenigvuldiging van de uitstroompercentages met de gediplomeerdenaantallen in een prognose van het aantal schoolverlaters dat het laatstgevolgde voltijdonderwijs met een diploma heeft afgerond. In figuur 2.1. is de methodiek ter raming van het toekomstige aantal gediplomeerde schoolverlaters met een diploma van de laatstgevolgde voltijdopleiding nog eens schematisch weergegeven.

\subsection{De prognose van het aantal schoolverlaters zonder diploma van de laatstgevolg- de voltijdopleiding}

De uitstroom uit het regulier voltijdonderwijs bestaat, zoals gezegd, niet alleen uit schoolverlaters die de laatstgevolgde voltijdopleiding met een diploma hebben afgesloten, maar ook uit schoolverlaters die de laatstgevolgde voltijdopleiding zonder diploma hebben beëindigd. Het startpunt voor de raming van het toekomstige aantal ongediplomeerde schoolverlaters ligt bij de aantallen schoolverlaters naar schoolsoort en diplomabezit uit de SKILL-prognoses. Hieruit kan voor elk van de hoofdschoolsoorten (algemeen voortgezet onderwijs, lager beroepsonderwijs, middelbaar beroepsonderwijs, etc.) het verwachte aantal schoolverlaters zonder diploma van het laatstgenoten voltijdonderwijs in de periode 1988/'89-1992/'93 worden berekend.

Reeds eerder werd opgemerkt, dat de codering van de onderwijskwalificaties van beroepsbeoefenaren in de AKT en de EBB plaatsvindt op grond van het hoogst behaalde onderwijsdiploma. Voor de raming van de toekomstige instroom van schoolverlaters op de arbeidsmarkt heeft dit als consequentie, dat van de schoolverlaters zonder diploma van de laatstgevolgde voltijdopleiding moet worden vastgesteld welke (voor)opleiding zij wel met succes hebben afgerond. Daartoe vindt eerst een bewerking van de onderwijsmatrix plaats, waarbij de doorstroom binnen dezelfde schoolsoort uit de onderwijsmatrix wordt verwijderd, zodat alleen de instroom en de doorstroom van de ene naar de andere schoolsoort overblijven. Vervolgens wordt een koppeling aangebracht tussen de in de SKILL-ramingen onderscheiden hoofdschoolsoorten en de indeling van het voltijdonderwijs in de onderwijsmatrix. Omdat in de onderwijsmatrix de ingeschrevenen in de leerjaren 2 en 3 van het hoger algemeen voortgezet onderwijs (HAVO) en het voorbereidend wetenschappelijk onderwijs (VWO) zijn samengevoegd, wordt met behulp van leerlingenaantallen naar leerjaar en geslacht uit de Statistiek van het vwo, havo en mavo 1989/'90 (Centraal Bureau voor de Statistiek, 1990d) een verdeelsleutel berekend, waarmee de HAVO- en VWO-leerlingen in de onderbouw kunnen worden uitgesplitst over HAVO en VWO afzonderlijk.

12. In totaal worden in de SKILL-gediplomeerdenraming 40 richtingen onderscheiden. De opleiding voor kleuterleidster (KLOS) wordt echter buiten beschouwing gelaten, omdat deze opleiding inmiddels is afgebouwd.

13. In het basisonderwijs en het (voortgezet) speciaalonderwijs worden geen diploma's uitgereikt, dus komen deze schoolsoorten, evenals trouwens het voltijd-KMBO, niet voor in de SKILL-gediplomeerdenraming. Het aantal gediplomeerden van de gecombineerde HAVO/MBO-opleiding wordt in de SKILL-prognoses wel geraamd, maar de gediplomeerden zijn toegerekend aan de afzonderlijke categoriale schoolsoorten (HAVO, middelbaar technisch onderwijs, middelbaar economisch en administratief onderwijs, etc.). 
Figuur 2.2. Methodiek ter raming van het toekomstig aantal schoolverlaters zonder diploma van de laatstgevolgde voltijdopleiding
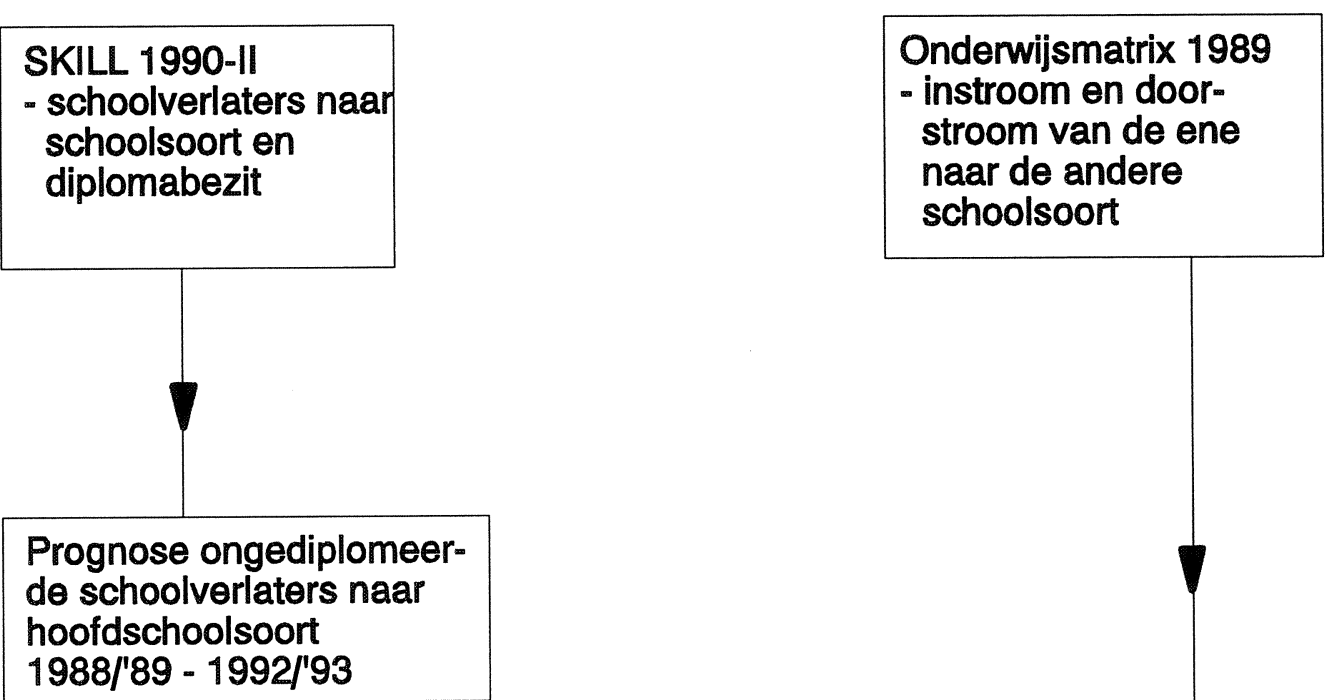

Koppeling SKILL-hoofdschoolsoorten/ CBS-schoolsoorten

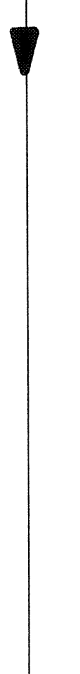

Procentuele verdeling instroom SKILL-hoofdschoolsoorten naar (CBS-) schoolsoort van herkomst 1989/'90

Prognose van het naar hun hoogst voltooide vooropleiding herleide aantal ongediplomeerde schoolverlaters uit het voltijdonderwijs naar CBSschoolsoort 
Met het koppelschema en de verdeelsleutel wordt de onderwijsindeling in de kolommen van de onderwijsmatrix aangepast aan de hoofdschoolsoorten uit SKILL. De schoolsoortenindeling in de rijen van de onderwijsmatrix blijft op één uitzondering na gehandhaafd. Het KMBO wordt eruit verwijderd, omdat de doorstroom van het KMBO naar het middelbaar beroepsonderwijs (MBO) volgens de SOI geen verandering in het opleidingsniveau teweeg brengt. De doorstroom van het KMBO naar andere hoofdschoolsoorten dan het MBO is zo gering dat deze kan worden verwaarloosd. Uit de aldus bewerkte onderwijsmatrix kan vervolgens voor elk van de in SKILL onderscheiden hoofdschoolsoorten de procentuele verdeling van de instroom naar schoolsoort van herkomst worden bepaald.

Door de procentuele verdeling van de instroom naar schoolsoort van herkomst in het jaar 1989/'90 te projecteren op de verwachte aantallen schoolverlaters zonder diploma van de laatstgevolgde voltijdopleiding worden de toekomstige ongediplomeerde schoolverlaters herleid tot gediplomeerde schoolverlaters van hun hoogst voltooide vooropleiding ${ }^{14}$. De bovenbeschreven ramingsmethodiek is schematisch samengevat in figuur 2.2 .

\subsection{De prognose van de totale uitstroom uit het regulier voltijdonderwijs per ROA- opleidingstype}

In de voorgaande twee paragrafen is beschreven op welke wijze een raming van de toekomstige aantallen schoolverlaters met en zonder diploma van hun laatstgevolgde voltijdopleiding is opgesteld, en hoe de ongediplomeerde schoolverlaters zijn herleid tot gediplomeerde schoolverlaters van hun hoogst voltooide vooropleiding. Door de laatsten op te tellen bij de schoolverlaters voor wie de overeenkomstige laatstgevolgde voltijdopleiding tevens de hoogst voltooide voltijdopleiding is, wordt voor 24 CBS-schoolsoorten een prognose van het totaal aantal schoolverlaters naar hoogst voltooide voltijdopleiding in de periode 1989-1994 verkregen. De opleidingenindeling van het ROA is echter verfijnder dan de schoolsoortenindeling van het CBS. Bovendien is de schoolsoortenindeling van het CBS een classificatie van onderwijsinstellingen, terwijl de onderwijsindeling van het ROA een classificatie van opleidingstypen inhoudt, vanwege de rechtstreekse koppeling aan de SOI (zie bijlage 1). Consequentie van een en ander is, dat de prognoses voor de 24 CBS-schoolsoorten moeten worden versleuteld naar de 49 ROAopleidingstypen.

De berekening van verdeelsleutels geschiedt op basis van aantallen geslaagden. Aan elk onderwijselement wordt een vijfcijferige code toegekend. De eerste twee cijfers representeren de schoolsoort, terwijl de laatste drie cijfers worden gevormd door de eerste drie digits van de SOI-code. Met behulp van de vijfcijferige code kan per schoolsoort het aandeel van een SOI-

14. Degenen die geen enkel diploma hebben behaald, worden beschouwd als 'gediplomeerde' schoolverlaters van het basisonderwijs. Uitzondering hierop vormen degenen die de bovenbouw van het HAVO of het VWO ongediplomeerd hebben verlaten. Zij worden in de SOI tot hetzelfde opleidingstype gerekend als degenen die een MAVO-diploma hebben behaald. Derhalve worden zij in de ROA-prognoses ook als gediplomeerde schoolverlaters van dit opleidingstype beschouwd. 
Figuur 2.3. Prognose van de toekomstige uitstroom uit het regulier voltijdonderwijs naar ROA-opleidingstype

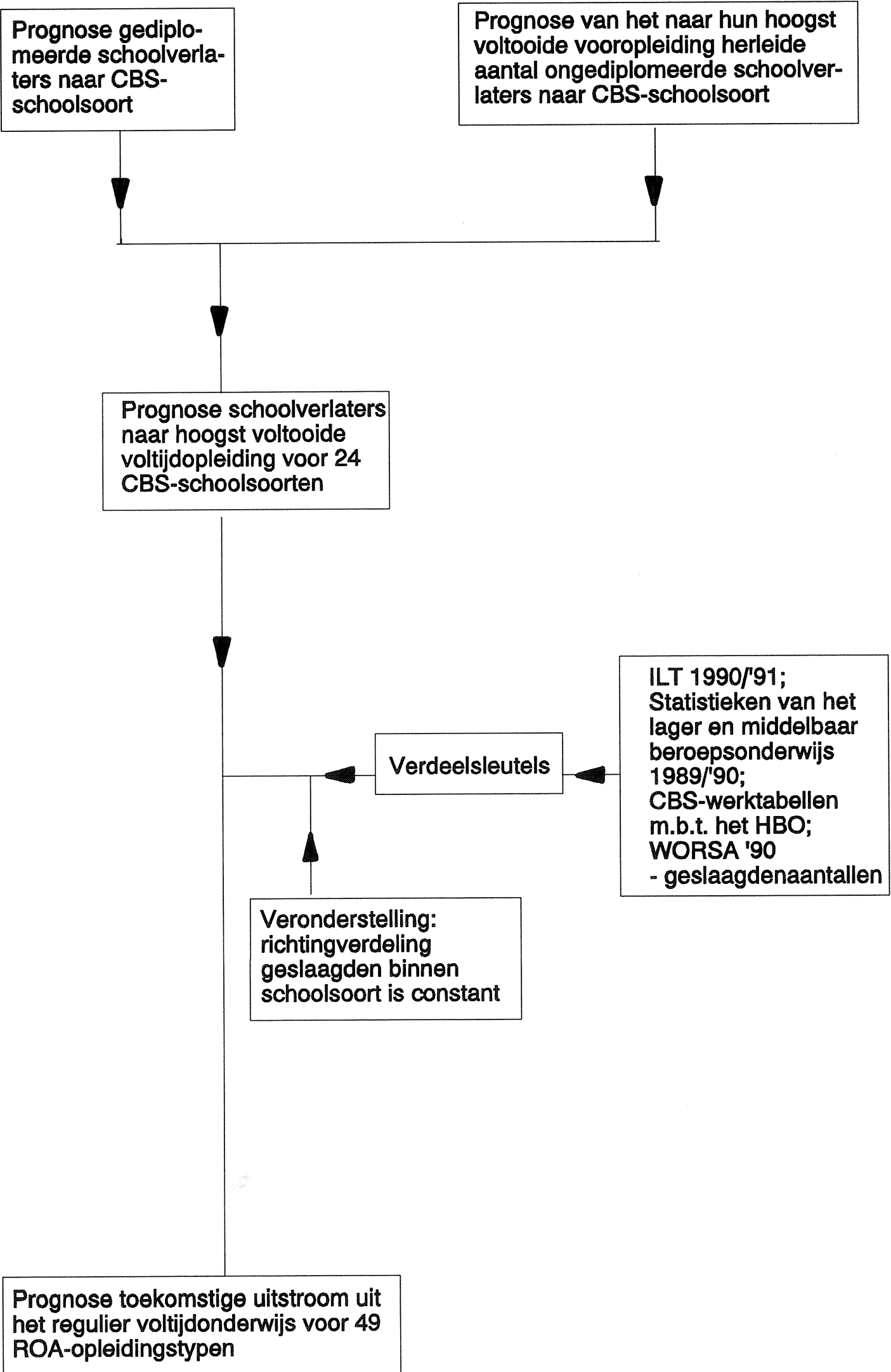


categorie in het totaal aantal geslaagden worden berekend. De geslaagdenaantallen van het algemeen voortgezet onderwijs (AVO), het LBO en het MBO worden ontleend aan de ILT $1990 /$ '91 en hebben betrekking op het schooljaar 1989/' 90 .

De ILT bevat slechts een zeer beperkt aantal gegevens over het lager en het middelbaar agrarisch onderwijs. Daarom worden de aantallen geslaagden van deze schoolsoorten onttrokken aan de onderwijsstatistieken van het CBS. Voor het lager agrarisch onderwijs wordt daarbij gebruik gemaakt van de Statistiek van het lager beroepsonderwijs 1989/'90 en voor het middelbaar agrarisch onderwijs van de Statistiek van het middelbaar beroepsonderwijs 1989/'90. In beide gevallen gaat het om de aantallen geslaagden in 1989. De aantallen geslaagden van het HBO worden ontleend aan de werktabellen die het CBS bij de samenstelling van de onderwijsmatrix gebruikt. Ook deze aantallen hebben betrekking op het jaar 1989. Bij de berekening van verdeelsleutels voor het WO is gebruik gemaakt van prognoses van het aantal afgestudeerden naar studierichting in de jaren 1988/'89-1992/'93 uit de WORSA '90-publicatie van de Taakgroep Studentenramingen ${ }^{15}$. De afgestudeerden in de landbouwwetenschappelijke studierichtingen zijn nog eens herverdeeld met aanvullend cijfermateriaal van de WORSAsamenstellers. Dit was noodzakelijk, omdat de WORSA-indeling van het wetenschappelijk landbouwonderwijs niet verfijnd genoeg is om een eenduidige koppeling met de SOI tot stand te brengen.

De berekende verdeelsleutels worden vermenigvuldigd met de raming van de verwachte aantallen 'gediplomeerde' schoolverlaters voor de 24 CBS-schoolsoorten. Vervolgens worden de uitkomsten van deze vermenigvuldiging gesommeerd per SOI-opleidingstype. $\mathrm{Na}$ aggregatie naar de ROA-indeling resulteert de gewenste prognose van de toekomstige uitstroom uit het regulier voltijdonderwijs voor de 49 ROA-opleidingstypen. In figuur 2.3. wordt het bovenstaande schematisch weergegeven.

15. De 'prognoses' voor het jaar 1988/'89 betreffen de gerealiseerde aantallen afgestudeerden. 


\section{DE PROGNOSE VAN DE GEDIPLOMEERDE UITSTROOM UIT HET REGU- LIER DEELTIJDONDERWIJS}

\subsection{Inleiding}

In het vorige hoofdstuk is beschreven op welke wijze de prognose van de uitstroom uit het regulier voltijdonderwijs tot stand is gekomen. Met deze prognose ligt de totale toekomstige instroom van schoolverlaters op de arbeidsmarkt vast. Degenen die uitstromen uit het regulier voltijdonderwijs kunnen echter doorstromen naar een vorm van regulier deeltijdonderwijs. Als iemand een reguliere deeltijdopleiding succesvol afrondt en de gevolgde opleiding ligt op een hoger niveau dan de genoten vooropleiding, leidt dat tot een daling van het arbeidsaanbod in de opleidingscategorie waartoe de vooropleiding behoort. Tegelijkertijd stijgt het aanbod in de opleidingscategorie waarbij de deeltijdopleiding is ondergebracht. Om hiermee rekening te houden, wordt op basis van eenvoudige doorrekenmethodieken een prognose van de gediplomeerde uitstroom uit het regulier deeltijdonderwijs (inclusief voltijd-KMBO) opgesteld, waarbij tevens de vooropleiding van de gediplomeerden wordt bepaald.

De prognose van de gediplomeerde uitstroom uit het regulier deeltijdonderwijs is opgebouwd uit vier deelprognoses:

- een prognose van de gediplomeerde uitstroom uit het voltijd-KMBO en het Leerlingwezen (LLW);

- een prognose van de gediplomeerde uitstroom uit de eerste fase van het deeltijd-HBO;

- een prognose van de gediplomeerde uitstroom uit de tweede fase van het HBO;

- een prognose van de gediplomeerde uitstroom uit de tweede fase-lerarenopleiding in het WO.

De verdere opzet van dit hoofdstuk correspondeert met deze opbouw. Nadat in paragraaf 3.2. een overzicht is gegeven van het gebruikte datamateriaal, wordt in paragraaf 3.3. ingegaan op de prognoses met betrekking tot het voltijd-KMBO en het LLW. In paragraaf 3.4. komt de prognose van de gediplomeerde uitstroom uit de eerste fase van het deeltijd-HBO aan de orde en paragraaf 3.5. beschrijft de totstandkoming van de raming van het toekomstig aantal afgestudeerden in de tweede fase van het HBO. In paragraaf 3.6. wordt besproken op welke wijze een prognose van het aantal gediplomeerden van de tweede fase-lerarenopleiding in het WO is opgesteld.

\subsection{Datamateriaal}

Bij de raming van de toekomstige gediplomeerde uitstroom uit het regulier deeltijdonderwijs is gebruik gemaakt van de volgende databronnen:

1. het bestand Opgave van Leerlingwezen (OVL) 1988/' 89 van het Ministerie van Onderwijs en Wetenschappen;

2. de SKILL-onderwijsprognoses;

3. de Raming Hoger Beroepsonderwijs Studentenaantallen (RHOBOS) 1990 van de Taakgroep Studentenramingen (Taakgroep Studentenramingen, 1990b); 
4. de CBS-onderwijsmatrix 1989;

5. de Statistiek van het hoger beroepsonderwijs $1987 /$ ' 88 en 1988/'89 (Centraal Bureau voor de Statistiek, 1990a);

6. de HBO-werktabellen die het CBS gebruikt bij de opstelling van de onderwijsmatrix;

7. cijfers van de Vereniging van Samenwerkende Nederlandse Universiteiten (VSNU) over de lerarenopleidingen in de tweede fase van het WO;

8. WORSA 1990.

De bronnen 2, 4, 6 en 8 zijn reeds in paragraaf 2.2. beschreven. Op de andere bronnen zal hieronder kort worden ingegaan.

Het $O V L$-bestand bevat tellingen van het aantal leerlingen in het voltijd-KMBO en het Leerlingwezen. De tellingen zijn uitgesplitst naar school, opleidingssoort (voltijd-KMBO of Leerlingwezen), cursussoort (primaire opleiding timmerkracht, primaire opleiding brood- en banketbakker, voortgezette opleiding timmerkracht, voortgezette opleiding brood- en banketbakker, etc.), leerjaar, geslacht, leeftijd en vooropleiding. Het OVL-bestand is samen met de SKILL-prognoses gebruikt om de prognose van de gediplomeerde uitstroom uit het voltijd-KMBO en het Leerlingwezen op te stellen.

Voor de prognose van de gediplomeerde uitstroom uit de eerste fase van het deeltijd-HBO dient de $R H O B O S$-raming als uitgangspunt. De RHOBOS-raming geeft prognoses van de jaarlijkse instroom, het aantal ingeschreven studenten en het aantal gediplomeerden in het HBO. De prognoses zijn uitgesplitst naar deelsector (pedagogische academie basisonderwijs, agrarisch, technisch, economisch \& administratief, etc.), geslacht en tijdsbeslag (voltijdonderwijs en deeltijdonderwijs). Tweede fase opleidingen worden niet in de ramingen betrokken.

Naast de RHOBOS-raming is voor de prognose van de gediplomeerde uitstroom uit het deeltijdHBO gebruik gemaakt van de onderwijsmatrix, de HBO-werktabellen en de Statistiek van het hoger beroepsonderwijs. Deze laatste statistiek bevat onder meer informatie over het aantal deeltijdstudenten naar schoolsoort en leeftijd.

Voor de prognose van de gediplomeerde uitstroom uit de tweede fase van het HBO zijn alleen de HBO-werktabellen gebruikt. De data ten behoeve van de prognose van het toekomstig aantal afgestudeerden van de tweede fase leraren opleidingen in het WO zijn afkomstig van twee bronnen. Van de VSNU zijn cijfers verkregen over de capaciteit van de post-doctorale lerarenopleidingen en over de ingeschrevenen bij die opleidingen in de jaren 1989, 1990 en 1991. Het aantal ingeschrevenen in het jaar 1988 is ontleend aan de WORSA-raming $1990^{16}$.

16. In de WORSA-ramingen worden weliswaar geen prognoses met betrekking tot tweede fase opleidingen gemaakt, maar in de WORSA-publicatie worden wel enkele historische gegevens over tweede fase opleidingen vermeld. 
3.3. De prognose van de gediplomeerde uitstroom uit het voltijd-KMBO en het Leerlingwezen

Uitgangspunt voor de prognose van de gediplomeerde uitstroom uit het voltijd-KMBO en het Leerlingwezen vormen de aantallen eerstejaars-leerlingen uit het OVL-bestand. Van alle leerlingen die in het studiejaar 1988/'89 aan een opleiding in het voltijd-KMBO of het Leerlingwezen zijn begonnen, wordt bepaald in welke cursussoort zij instroomden en over welke vooropleiding zij beschikten. Vervolgens is per cursussoort berekend hoeveel leerlingen een vooropleiding hadden die lager was dan het niveau van de desbetreffende cursussoort. Alleen van deze leerlingen zou immers door het volgen van een KMBO- of Leerlingwezenopleiding de hoogst verworven onderwijskwalificatie kunnen veranderen.

Om tot een prognose van de gediplomeerde uitstroom uit het voltijd-KMBO en het Leerlingwezen voor de gehele periode 1989-1994 te komen, is met name rekening gehouden met de op basis van demografische ontwikkelingen verwachte afname van het aantal gediplomeerden van de potentiële vooropleidingen. Daarvoor is een zogenaamde demografische factor berekend, die wordt gedefinieerd als het quotiënt van het aantal MAVO- en LBO-gediplomeerden in de periode 1988-1993 en het aantal MAVO- en LBO-gediplomeerden in het jaar 1988 ${ }^{17}$. Vermenigvuldiging van deze factor met het aantal leerlingen dat in 1988/'89 aan een niveauverhogende opleiding in het KMBO of het LLW begon, resulteert in een prognose van het aantal leerlingen dat in de periode 1989-1994 een niveauverhogende voltijd-KMBO- of LLW-cursus gaat volgen.

Op grond van informatie uit verschillende externe bronnen (Ministerie van Sociale Zaken en Werkgelegenheid (1988); Bisschop, Nijhof en Van Wieringen (1988); Bronneman-Helmers (1988)) kan het gemiddelde rendement in het voltijd-KMBO en het LLW op circa $70 \%$ worden geschat ${ }^{18}$. Door het verwachte aantal leerlingen dat in de periode 1989-1994 een niveauverhogende cursus gaat volgen met dit percentage te vermenigvuldigen, wordt een prognose verkregen van het aantal leerlingen dat in de periode 1989-1994 een niveauverhogend diploma in het voltijd-KMBO of het LLW zal behalen. Deze prognose is zowel uitgesplitst naar cursussoort als naar vooropleiding.

3.4. De prognose van de gediplomeerde uitstroom uit de eerste fase van het deeltijdHBO

Bij het opstellen van een prognose van de gediplomeerde uitstroom uit de eerste fase van het deeltijd-HBO wordt voortgebouwd op de RHOBOS-raming van het verwachte aantal afgestudeerden in de periode 1988/'89-1992/'93. Voor deze periode zijn de RHOBOS-prognoses met

17. De aantallen MAVO- en LBO-gediplomeerden zijn ontleend aan de SKILL-ramingen betreffende de gediplomeerden naar opleidingsniveau.

18. Meer recentelijk is een onderzoek verricht dat op een aanmerkelijk lager overall rendement (circa 51\%) uitkomt (zie Ganga, 1992). 
betrekking tot het deeltijd-HBO uitgesplitst naar 15 deelsectoren (leraar voortgezet onderwijs, pedagogisch technisch, economisch \& administratief, sociale academie, etc.). De deelsectorindeling spoort niet met de SOI en de ROA-opleidingenindeling. Dit impliceert dat een koppeling moet worden aangebracht tussen de RHOBOS-deelsectorindeling en de SOI. Met behulp van deze koppeling worden de prognoses voor de RHOBOS-deelsectoren versleuteld naar SOIopleidingstypen. Dit gebeurt op basis van geslaagdenaantallen uit de HBO-werktabellen van het CBS. De gebruikte cijfers hebben betrekking op het jaar 1989.

Een aantal afgestudeerden van het deeltijd-HBO stroomt door naar een vervolgopleiding in het voltijdonderwijs. Deze afgestudeerden dienen in mindering te worden gebracht op het totaal aantal gediplomeerden van het deeltijd-HBO, omdat zij niet beschikbaar zijn voor de arbeidsmarkt. Daarbij wordt verondersteld dat dit percentage hetzelfde is als het op basis van de onderwijsmatrix berekende percentage gediplomeerden van het voltijd-HBO dat doorstroomt naar een vervolgopleiding in het voltijdonderwijs (zie paragraaf 2.3.). Dit percentage wordt geprojecteerd op het verwachte aantal gediplomeerden van het deeltijd-HBO. Het resultaat is een prognose van het aantal afgestudeerden van het deeltijd-HBO per SOI-opleidingstype, dat geen voltijdonderwijs gaat volgen. Voor een deel van deze afgestudeerden is de gevolgde opleiding niet beroepsgericht. Om hiervoor te corrigeren, wordt er van uit gegaan dat de gevolgde opleiding alleen beroepsgericht is voor afgestudeerden die jonger zijn dan 30 jaar. Voor deze leeftijdscorrectie wordt gebruik gemaakt van de Statistiek van het hoger beroepsonderwijs 1987/' 88 en 1988/'89. Hierbij gaat het om de aantallen studenten in de hoofdfase van het deeltijd-HBO, uitgesplitst naar schoolsoort en leeftijd. Nadat een koppeling is aangebracht tussen de in de Statistiek van het hoger beroepsonderwijs onderscheiden schoolsoorten en de RHOBOS-deelsectorindeling, wordt het percentage studenten dat in het studiejaar 1988/'89 jonger is dan 30 jaar geprojecteerd op het verwachte aantal afgestudeerden van het deeltijd$\mathrm{HBO}$, dat geen voltijdonderwijs gaat volgen. Daarmee ontstaan prognoses van het arbeidsaanbod van afgestudeerden van het deeltijd-HBO per SOI-opleidingstype, die vervolgens worden geaggregeerd naar ROA-opleidingstypen.

Om de vooropleiding van het verwachte arbeidsaanbod van afgestudeerden van het deeltijdHBO te bepalen, wordt gebruik gemaakt van de onderwijsmatrix 1989 . Hieruit wordt voor het voltijd-HBO de verdeling van de instroom naar vooropleiding (schoolsoort van herkomst) in het schooljaar 1989/'90 afgeleid. Door deze verdeling te projecteren op het verwachte arbeidsaanbod van afgestudeerden van het deeltijd-HBO, wordt een opsplitsing naar schoolsoort van herkomst verkregen. Met behulp van de verdeelsleutels die voor het opstellen van de prognose van de uitstroom uit het regulier voltijdonderwijs zijn berekend (zie paragraaf 2.5.), wordt de opsplitsing naar schoolsoort van herkomst getransformeerd naar de ROA-opleidingenindeling. Aldus resulteert de prognose van het arbeidsaanbod van afgestudeerden van het deeltijd-HBO naar vooropleiding volgens de indeling in ROA-opleidingstypen. 


\subsection{De prognose van de gediplomeerde uitstroom uit de tweede fase van het HBO}

$\mathrm{Na}$ het afsluiten van de eerste fase van het HBO kunnen de afgestudeerden doorstromen naar de tweede fase. Deze doorstroom is niet in de SKILL- en RHOBOS-prognoses verdisconteerd. Dit heeft tot gevolg dat een afzonderlijke prognose van de gediplomeerde uitstroom uit de tweede fase van het $\mathrm{HBO}$ moet worden opgesteld, omdat een aantal van deze tweede fase opleidingen in de SOI qua opleidingsniveau wordt getypeerd als een universitaire opleiding. Daarbij wordt uitgegaan van de aantallen afgestudeerden van de tweede fase opleidingen in het studiejaar 1988/'89. In dat jaar waren er vijf HBO-schoolsoorten die afgestudeerden van tweede fase opleidingen afleverden: het hoger gezondheidszorgonderwijs (HGZO), het hoger economisch onderwijs (HEO), het hoger sociaal-agogisch onderwijs (HSAO), het hoger kunstonderwijs (HKO) en het hoger pedagogisch onderwijs (HPO). De desbetreffende cijfers zijn te vinden in de HBOwerktabellen die het CBS gebruikt bij het opstellen van de onderwijsmatrix.

Om tot een prognose van het aantal afgestudeerden in de periode 1989-1994 te komen, wordt verondersteld dat het jaarlijkse aantal afgestudeerden gehandhaafd blijft op het niveau van het basisjaar 1988/'89. De hierdoor verkregen prognose is gedifferentieerd naar SOI-opleidingstype. Door er van uit te gaan dat alle afgestudeerden zich op de arbeidsmarkt begeven, wordt vervolgens op eenvoudige wijze een prognose van de gediplomeerde uitstroom uit de tweede fase opleidingen van het $\mathrm{HBO}$, geaggregeerd naar ROA-opleidingstypen, verkregen.

Voor de bepaling van de vooropleiding van de afgestudeerden van de tweede fase opleidingen in het HBO ontbreken adequate gegevens. Derhalve worden hiervoor een aantal in meer of mindere mate arbitraire regels gehanteerd:

- ten aanzien van de afgestudeerden van de pedagogisch-didactische tweede fase opleiding wordt verondersteld dat zij een vooropleiding in één van de hoofdrichtingen van het HPO hebben gehad;

- ten aanzien van de afgestudeerden van de tweede fase opleiding leraar nautisch onderwijs wordt verondersteld dat zij een vooropleiding in éen van de hoofdrichtingen van het hoger nautisch onderwijs (HNO) hebben gehad;

- ten aanzien van de afgestudeerden van de tweede fase opleidingen beroepsinnovatie en manager gezondheidszorg wordt verondersteld dat zij een vooropleiding in één van de hoofdrichtingen van het HGZO hebben gehad;

- ten aanzien van de afgestudeerden van de tweede fase opleiding zelfstandig ondernemer wordt verondersteld dat zij een vooropleiding in één van de hoofdrichtingen van het HEO hebben gehad;

- ten aanzien van de afgestudeerden van de tweede fase opleidingen kadercursus opbouwwerk en voortgezette agogische beroepsopleiding wordt verondersteld dat zij een vooropleiding in één van de hoofdrichtingen van het HSAO hebben gehad;

- ten aanzien van de afgestudeerden van de tweede fase opleidingen aantekening muziek en kunstmanagement, -bemiddeling en -beleid wordt verondersteld dat zij een vooropleiding in één van de hoofdrichtingen van het HKO hebben gehad;

- ten aanzien van de afgestudeerden van de tweede fase opleiding bouwkunstonderwijs- 
architectuur, wordt verondersteld dat zij een vooropleiding bouwkunde of weg- en waterbouwkunde in het hoger technisch en natuurwetenschappelijk onderwijs (HTNO) of een opleiding architectonische vormgeving in het HKO hebben gehad.

- ten aanzien van de afgestudeerden van de tweede fase opleiding bouwkunstonderwijslandschapsarchitectuur, wordt verondersteld dat zij een vooropleiding tuin- en landschapsinrichting of bosbouw- en cultuurtechniek in het hoger agrarisch onderwijs (HAO) hebben gehad;

- ten aanzien van de afgestudeerden van de tweede fase opleiding bouwkunstonderwijsstedebouwkunde, wordt verondersteld dat zij een vooropleiding bouwkunde of weg- en waterbouwkunde in het HTO, een opleiding tuin- en landschapsinrichting, bosbouw of cultuurtechniek in het HAO of een opleiding architectonische vormgeving in het HKO hebben gehad.

Voor de drie laatstgenoemde tweede fase opleidingen moeten sleutels worden berekend om de afgestudeerden naar de desbetreffende vooropleidingen te verdelen. Dit gebeurt aan de hand van de geslaagdenaantallen in de eerste fase van het voltijd-HBO in het studiejaar 1988/'89. Deze aantallen worden ontleend aan de HBO-werktabellen van het CBS. De verdeling naar vooropleiding is gedifferentieerd naar SOl-opleidingstype en wordt vervolgens getransformeerd naar de ROA-opleidingenindeling, zodat een prognose ontstaat van de arbeidsmarktinstroom van afgestudeerden van het tweede fase $\mathrm{HBO}$, uitgesplitst naar vooropleiding.

\subsection{De prognose van de gediplomeerde uitstroom uit de tweede fase lerarenopleiding van het WO}

$\mathrm{Na}$ het behalen van het doctoraal examen, hebben WO-studenten de mogelijkheid een postdoctorale opleiding te gaan volgen. De toekomstige afgestudeerden van deze tweede fase opleidingen worden in de SKILL-raming ondergebracht bij de studierichting waarin ze de desbetreffende opleiding volgen. Dit heeft tot gevolg dat degenen die in de tweede fase van het WO een lerarenopleiding succesvol afsluiten niet afzonderlijk worden onderscheiden, maar worden toegerekend aan hun oorspronkelijke discipline. Er dient dus een correctie op de prognose van de gediplomeerde uitstroom uit het WO te worden aangebracht, omdat de afgestudeerden van tweede fase lerarenopleidingen in de SOI wel tot een afzonderlijk opleidingstype worden gerekend. Het gegevensmateriaal dat hiervoor wordt gebruikt, is afkomstig van de VSNU en heeft betrekking op de jaarlijkse maximale capaciteit van de verschillende tweede fase lerarenopleidingen en de ingeschrevenen bij die opleidingen in de jaren 1989, 1990 en 1991. Aan WORSA 1990 is het aantal ingeschrevenen in het jaar 1988 ontleend.

Bij het opstellen van een prognose van de gediplomeerde uitstroom uit de tweede fase lerarenopleidingen in het WO wordt er van uit gegaan dat de opleidingsduur één jaar bedraagt. Daarnaast wordt aangenomen dat het rendement op 100\% kan worden gesteld. Dit heeft als consequentie dat de instroom in jaar $t$ gelijk is aan het aantal ingeschrevenen in jaar $t$ en dat de gediplomeerde uitstroom in jaar $\mathrm{t}+1$ gelijk is aan de instroom in jaar $\mathrm{t}$. Zoals gezegd, zijn er voor de jaren 1988-1991 ingeschrevenencijfers beschikbaar. Derhalve kan de gediplomeerde 
uitstroom in de jaren 1989-1992 eenvoudig worden berekend. Voor het jaar 1993 moet een andere werkwijze worden gevolgd om tot een prognose van de gediplomeerde uitstroom te komen. Allereerst is per discipline een analyse gemaakt van de ontwikkeling van het aantal ingeschrevenen in de tweede fase lerarenopleidingen van het WO in de jaren 1988-1991. Indien het aantal ingeschrevenen in een bepaalde discipline een stijgende trend vertoont, wordt deze trendmatige ontwikkeling geëxtrapoleerd naar het jaar 1992. Komt het verwachte aantal ingeschrevenen daardoor boven de maximale jaarlijkse opleidingscapaciteit, dan wordt het aantal ingeschrevenen in dat jaar op het niveau van de maximale capaciteit gesteld. Indien er in één of meer jaren geen inschrijvingen zijn gerealiseerd, wordt het verwachte aantal ingeschrevenen in 1992 gelijk gesteld aan het maximum van het aantal ingeschrevenen in de jaren 19881991.

Op grond van de gemaakte veronderstellingen ligt met de prognose van het aantal ingeschrevenen in het jaar 1992 tegelijkertijd de verwachte gediplomeerde uitstroom in 1993 vast. Door deze laatste te combineren met de uitstroomprognoses voor de jaren 1989-1992, ontstaat voor elke tweede fase lerarenopleiding een prognose van de gediplomeerde uitstroom voor de gehele prognoseperiode. Door een koppeling aan te brengen tussen de VSNU- en de WORSA-indeling van de oorspronkelijke disciplines van de afgestudeerden enerzijds en de SOI anderzijds, kan vervolgens de benodigde correctie op de verwachte gediplomeerde uitstroom uit de WOopleidingstypen in het ROA-informatiesysteem worden aangebracht. 


\section{DE PROGNOSE VAN DE GEDIPLOMEERDE UITSTROOM UIT EEN AANTAL NIET-REGULIERE OPLEIDINGEN}

\subsection{Inleiding}

Degenen die uitstromen uit het regulier voltijdonderwijs, kunnen niet alleen doorstromen naar het regulier deeltijdonderwijs, maar ook naar het niet-regulier onderwijs, hetzij in voltijdse vorm, hetzij in deeltijdse vorm. Evenals voor het regulier deeltijdonderwijs geldt ook voor het nietregulier onderwijs dat het succesvol afsluiten van een opleiding een verschuiving in de verdeling van het arbeidsaanbod naar opleidingstype teweeg brengt, indien de gevolgde opleiding op een hoger niveau ligt dan de genoten vooropleiding. Om hiervoor een correctie aan te brengen op de verwachte uitstroom uit het regulier voltijdonderwijs, is het noodzakelijk een prognose op te stellen van de gediplomeerde uitstroom uit het niet-regulier onderwijs waarbij derhalve ook de vooropleiding van de gediplomeerden in ogenschouw moet worden genomen.

Op basis van de momenteel beschikbare informatie is het onmogelijk een volledig beeld te geven van het aantal geslaagden in alle bestaande niet-reguliere onderwijsvormen waarbij er mogelijk sprake kan zijn van een (substantiële) verhoging van het opleidingsniveau van het arbeidsaanbod. Derhalve is geprobeerd vooral ook voor de ROA-opleidingstypen waarbij het arbeidsaanbod in belangrijke mate wordt bepaald door niet-reguliere beroepsopleidingen indicatieve prognoses op te stellen van de gediplomeerde uitstroom uit de desbetreffende opleidingen. Het gaat daarbij met name om opleidingen die ressorteren onder de opleidingstypen LBO Beveiliging \& Bewaking, MBO Verpleging \& Ziekenverzorging, MBO Politie \& Defensie en HBO Politie \& Defensie. Daarnaast zijn ook voor enkele andere niet-reguliere opleidingen indicatieve prognoses opgesteld.

Per saldo zijn voor de volgende vormen van niet-regulier onderwijs prognoses opgesteld:

- onderwijs in de openbare orde en veiligheid (politie-, defensie- en brandweeropleidingen alsmede particuliere bewakingsopleidingen);

- in-service-onderwijs (verpleegkunde A, B en $\mathrm{Z}$ alsmede ziekenverzorging);

- enkele andere niet-reguliere opleidingen (Rijksacademies van Beeldende Kunsten, Universiteit voor bedrijfskunde Nijenrode en de opleiding tot registeraccountant van het Nederlands Instituut van Registeraccountants).

Deze prognoses zijn doorgaans tot stand gekomen op basis van eenvoudige doorrekenmethodieken.

In het vervolg van dit hoofdstuk worden de verschillende deelprognoses successievelijk besproken. Daaraan voorafgaand wordt in paragraaf 4.2 . eerst een beschrijving gegeven van de gebruikte data. 


\subsection{Datamateriaal}

Voor het opstellen van de prognose van de toekomstige gediplomeerde uitstroom uit het nietregulier onderwijs is gebruik gemaakt van de volgende data c.q. databronnen:

1. opleidingsgegevens van het Landelijk Selektiecentrum voor de politie;

2. opleidingsgegevens van het Ministerie van Defensie;

3. gegevens van het CBS over de opleiding tot brandweerofficier;

4. opleidingsgegevens van de Stichting Vakopleiding Particuliere Beveiligingsorganisaties (SVPB);

5. opleidingsgegevens van het Centraal Wervings- en Opleidingsinstituut voor het Gevangeniswezen (CWOI);

6. opleidingsgegevens van de Geneeskundige Hoofdinspectie van de Volksgezondheid (GHI) van het Ministerie van Welzijn, Volksgezondheid en Cultuur (WVC);

7. opleidingsgegevens van de Geneeskundige Hoofdinspectie voor de Geestelijke Volksgezondheid (GHIGV) van het Ministerie van WVC;

8. opleidingsgegevens uit het rapport De arbeidsmarkt voor verpleegkundigen en ziekenverzorgenden; proefproject in het noorden van het land van het Nationaal Ziekenhuisinstituut (Nationaal Ziekenhuisinstituut, 1987);

9. opleidingsgegevens van de Rijksacademies van Beeldende Kunsten;

10. onderwijsgegevens uit het Statistisch jaarboek 1990 van het CBS (Centraal Bureau voor de Statistiek, 1990e);

11. de onderwijsmatrix 1989 van het $\mathrm{CBS}$;

12. de jaarverslagen $1985 /$ ' 86 tot en met 1989/' 90 van het Nederlands Instituut van Registeraccountants (NIVRA) betreffende de NIVRA-opleiding en het NIVRA-examen.

Via het Landelijk Selektiecentrum voor de politie (LSP) zijn opleidingsgegevens verkregen van de Nederlandse Politie Academie (NPA) enerzijds en de Primaire Opleidingsschool en de Herziene Politie Opleiding anderzijds. De cijfers van de NPA hebben betrekking op de instroom naar opleidingssoort (verbijzonderd naar dagstudenten, extraneï, academici en allochtonen) en vooropleiding in de jaren 1990 en 1991 en de verwachte instroom per opleidingssoort in het jaar 1992. Daarnaast is een globale indicatie van het gemiddelde rendement van de NPAopleidingen verkregen. Het datamateriaal van de Primaire Opleidingsschool en de Herziene Politie Opleiding betreft de instroom naar vooropleiding en geslacht in de maanden januari en april 1991, informatie over de startdata van de opleiding en een globale indicatie van het gemiddelde rendement. De LSP-gegevens zijn gebruikt om een prognose van de gediplomeerde uitstroom uit politie-opleidingen op te stellen.

Voor de prognose van de gediplomeerde uitstroom uit de opleidingen tot beroepsmilitair is gebruik gemaakt van opleidingsgegevens van het Ministerie van Defensie. Daarbij gaat het om indicaties van het gemiddelde jaarlijkse aantal geslaagden van de opleidingen van de Koninklijke Marine (KM), de Koninklijke Landmacht (KL) en de Koninklijke Luchtmacht (KLu) op MBO-niveau naar vooropleiding, cijfers van de Koninklijke Militaire Academie (KMA) inzake de instroom naar vooropleiding in de jaren 1985/'86-1989/'90 en de gediplomeerde uitstroom naar vooropleiding 
in de jaren 1988/'89 en 1989/'90 alsmede indicaties van de gemiddelde jaarlijkse aantallen afstudeerders naar vooropleiding van het Koninklijk Instituut voor de Marine (KIM), het Opleidingscentrum Officieren Speciale Diensten (OCOSD) en de Luchtmachtofficierenschool (LUOS). Dit is aangevuld met informatie over de opleidingsduur van de KMA.

Bij de prognose van de gediplomeerde uitstroom uit brandweeropleidingen is uitgegaan van een door de het CBS verstrekte opgave van het aantal geslaagden voor de opleiding tot brandweerofficier in de jaren 1988/'89 en 1989/'90.

De prognose van de gediplomeerde uitstroom uit bewakingsopleidingen steunt op gegevens van de SVPB en het CWOI. De SVPB-gegevens hebben betrekking op het aantal geslaagden voor de opleiding Basisdiploma beveiliging en het Vakdiploma beveiliging in de maanden oktober 1989, maart 1990, oktober 1990 en maart 1991. Daarnaast zijn van de SVPB (globale) indicaties verkregen van het gemiddelde jaarlijkse aantal geslaagden voor het Kaderdiploma beveiliging en de vooropleiding van de geslaagden voor de particuliere bewakingsopleidingen. Het CWOI heeft een opgave verstrekt van het aantal geslaagden voor de opleiding tot bewaarder penitentiaire inrichting in de jaren 1989/'90 en 1990/'91.

De prognose van de gediplomeerde uitstroom uit het in-service-onderwijs is hoofdzakelijk gebaseerd op gegevens van de GHI en de GHIGV. Van de GHI zijn cijfers verkregen over de inen uitstroom van de opleidingen voor verpleegkunde $A$ en Ziekenverzorging $(Z V)$ in de jaren 1984-1990. De GHIGV-data hebben betrekking op de in- en uitstroom van de opleidingen voor verpleegkunde $B$ en $Z$ in dezelfde jaren. Voor de jaren 1985-1990 zijn de instroomcijfers van de GHIGV uitgesplitst naar vooropleiding en geslacht. De GHI-data over de A- en de ZV-opleidingen zijn aangevuld met gegevens over de verdeling van de instroom naar vooropleiding in de periode 1980-1985. Deze gegevens zijn ontleend aan het rapport De arbeidsmarkt voor verpleegkundigen en ziekenverzorgenden; proefproject in het noorden van het land van het Nationaal Ziekenhuisinstituut (NZi).

Ten behoeve van de prognose van de gediplomeerde uitstroom uit de andere in paragraaf 4.1. genoemde niet-reguliere opleidingen is door de Rijksacademies van Beeldende Kunsten een indicatie gegeven van het gemiddelde jaarlijkse aantal afstudeerders. Daarnaast zijn aan het Statistisch jaarboek 1990 van het CBS gegevens ontleend over het aantal geslaagden aan de Universiteit voor Bedrijfskunde (Nijenrode) in het jaar 1987/'88. Om de vooropleiding van de afgestudeerden te bepalen, is gebruik gemaakt van de onderwijsmatrix 1989 van het CBS. Voor het opstellen van de prognose van de gediplomeerde uitstroom uit de NIVRA-opleiding zijn de jaarverslagen van de NIVRA-opleiding en het NIVRA-examen gebruikt. Daarbij gaat het met name om cijfers over het aantal afgestudeerden van de NIVRA-opleiding in de jaren 1983/'841989/'90 en over de jaarlijkse instroom naar vooropleiding en studiefase (nog studerend, geslaagd of uitgeschreven) in de jaren 1972/'73-1985/' 86 (cohortcijfers). Aan het jaarverslag $1989 / 90$ is informatie ontleend over het gemiddelde rendement en de gemiddelde studieduur naar vooropleiding. 


\subsection{De prognose van de gediplomeerde uitstroom uit het onderwijs in de openbare orde en veiligheid}

Het eerste onderdeel van de prognose van de gediplomeerde uitstroom uit het onderwijs in de openbare orde en veiligheid is de prognose van de gediplomeerde uitstroom uit politie-opleidingen. Hiertoe wordt eerst een prognose opgesteld van het toekomstige aantal afstudeerders van de NPA. Op basis van cijfers over de (verwachte) instroom naar opleidingssoort en een globale indicatie van het gemiddelde rendement ${ }^{19}$ is een schatting gemaakt van de gemiddelde jaarlijkse uitstroom van de NPA-opleidingen. Door de te verwachten jaarlijkse gediplomeerde uitstroom gelijk te stellen aan dit gemiddelde, wordt een prognose verkregen van de gediplomeerde uitstroom in de periode 1989-1994. De vooropleiding van het verwachte aantal afstudeerders wordt bepaald door de verdeling van de instroom naar vooropleiding in de jaren 1990 en 1991 op de verwachte uitstroom te projecteren.

Naast de prognose van het toekomstige aantal afstudeerders van de NPA wordt een prognose opgesteld van het verwachte aantal geslaagden van de Primaire Opleidingsschool en de Herziene Politie Opleiding. Daarbij wordt uitgegaan van cijfers over de instroom naar vooropleiding (en geslacht) in de maanden januari en april 1991. Op basis van het gegeven dat men deze opleiding normaliter vier keer per jaar (in de maanden januari, april, juli en oktober) start en een globale indicatie van het gemiddelde rendement ${ }^{20}$, is een schatting gemaakt van de gemiddelde jaarlijkse uitstroom naar vooropleiding. Door er van uit te gaan dat het te verwachten jaarlijkse aantal geslaagden gedurende de prognoseperiode gelijk is aan dit gemiddelde, ontstaat een prognose van de gediplomeerde uitstroom naar vooropleiding voor de gehele prognoseperiode.

Het tweede onderdeel van de prognose van de gediplomeerde uitstroom uit het onderwijs in de openbare orde en veiligheid wordt gevormd door de prognose van de gediplomeerde uitstroom uit de opleidingen tot beroepsmilitair. Hierbij gaat het om opleidingen op MBO- en HBO-niveau. Voor de prognose van de gediplomeerde uitstroom van de opleidingen op MBO-niveau wordt gebruik gemaakt van indicaties van het gemiddelde jaarlijkse aantal geslaagden naar vooropleiding bij de opleidingen van de drie krijgsmachtonderdelen ( $K M, K L$ en $K L u$ ). Evenals bij de politie-opleidingen wordt er van uit gegaan dat het te verwachten aantal jaarlijkse geslaagden gelijk is aan dit gemiddelde, zodat een prognose van de gediplomeerde uitstroom naar vooropleiding in de gehele prognoseperiode wordt verkregen.

19. Het gemiddelde rendement van de NPA-opleidingen bedraagt bijna $100 \%$. Voor allochtonen ligt dit percentage echter lager. Derhalve is bij het opstellen van de prognose uitgegaan van een rendement van $100 \%$ voor dagstudenten, extraneï en academici en een rendement van $60 \%$ voor allochtonen.

20. Het gemiddelde rendement van de Primaire Opleidingsschool en de Herziene Politie Opleiding bedraagt circa $90 \%$. Bij de prognoses is uitgegaan van dit percentage. 
Bij het opstellen van prognoses met betrekking tot de toekomstige gediplomeerde uitstroom van militaire opleidingen op HBO-niveau wordt een onderscheid gemaakt tussen de opleidingen van het KIM, het OCOSD en de LUOS enerzijds en de KMA anderzijds. Van het KIM, het OCOSD en de LUOS zijn alleen indicaties beschikbaar van de gemiddelde jaarlijkse aantallen afstudeerders naar vooropleiding. Derhalve is voor het opstellen van prognoses voor deze opleidingen eenzelfde werkwijze gevolgd als voor de opleidingen op MBO-niveau. De prognose van het toekomstig aantal afstudeerders van de KMA is echter op een andere manier tot stand gekomen. Op grond van het gegeven dat deze opleiding nominaal vier jaar en drie maanden duurt, kan met behulp van cijfers inzake de instroom naar vooropleiding in de jaren 1985/' 86 en $1986 /$ ' 87 en de gediplomeerde uitstroom naar vooropleiding in de jaren 1988/' 89 en 1989/'90 een gemiddeld rendement worden berekend. Door dit rendement te projecteren op de instroom naar vooropleiding in de jaren 1987/'88-1989/'90, ontstaat een prognose van de gediplomeerde uitstroom naar vooropleiding in de jaren 1990/'91-1992/'93. Door deze te combineren met de feitelijke uitstroomgegevens voor de jaren 1988/' 89 en 1989/'90 wordt vervolgens een raming van de gediplomeerde uitstroom voor de gehele prognoseperiode verkregen.

De prognose van de gediplomeerde uitstroom uit brandweeropleidingen is het derde onderdeel van de raming van de gediplomeerde uitstroom uit het onderwijs in de openbare orde en veiligheid. Voor het opstellen van deze prognose is gebruik gemaakt van een door het CBS verstrekte opgave van het aantal geslaagden voor de opleiding tot brandweerofficier in de jaren 1988/'89 en 1989/'90. Op grond hiervan wordt het gemiddelde jaarlijkse aantal geslaagden berekend. Door er van uit te gaan dat dit gemiddelde in de jaren 1990/'91-1992/'93 op hetzelfde niveau zal blijven liggen, wordt een prognose verkregen van de toekomstige gediplomeerde uitstroom van de opleiding tot brandweerofficier. Aangezien voor deze opleiding een VWO-opleiding is vereist, zijn voor het vaststellen van de vooropleiding van de afstudeerders geen extra berekeningen noodzakelijk.

Het vierde en laatste onderdeel van de prognose van de gediplomeerde uitstroom uit het onderwijs in de openbare orde en veiligheid wordt gevormd door de prognose van de gediplomeerde uitstroom uit bewakingsopleidingen. Daarbij gaat het om het Basisdiploma beveiliging, het Vakdiploma beveiliging en het Kaderdiploma beveiliging van de SVPB en de opleiding tot gevangenisbewaarder van het CWOI. Op basis van het aantal geslaagden voor het Basisdiploma beveiliging en het Vakdiploma beveiliging in de maanden oktober 1989, maart 1990, oktober 1990 en maart 1991 wordt het aantal geslaagden voor deze opleidingen in de jaren 1989/'90 en 1990/' 91 berekend. Door het gemiddelde hiervan te beschouwen als een benadering van het (te verwachten) aantal geslaagden in de jaren 1988/'89, 1991/'92 en 1992/'93 wordt voor beide opleidingen een prognose verkregen van de gediplomeerde uitstroom in de gehele prognoseperiode. Over de vooropleiding van de gediplomeerden bestaan geen harde gegevens. De verdeling van de prognose van de gediplomeerde uitstroom naar vooropleiding geschiedt derhalve op grond van enkele globale indicaties van de SVPB. Volgens deze stichting heeft circa de helft van de geslaagden voor het Basisdiploma beveiliging basisonderwijs als hoogste vooropleiding. De rest heeft LBO of MAVO als hoogste vooropleiding. Derhalve is slechts $50 \%$ van de geslaagden voor het Basisdiploma in de herverdeling van de uitstroom uit het regulier 
voltijdonderwijs verdisconteerd. De opleiding is immers alleen niveauverhogend voor de gediplomeerden die basisonderwijs als hoogste vooropleiding hebben. Het Vakdiploma beveiliging kan slechts worden behaald nadat het Basisdiploma is behaald. De geslaagden voor het Vakdiploma hebben dus altijd het Basisdiploma als vooropleiding.

Voor de prognose van het toekomstige aantal geslaagden voor het Kaderdiploma beveiliging is gebruik gemaakt van een globale indicatie van het gemiddelde jaarlijkse aantal geslaagden. Er van uit gaande dat de jaarlijkse gediplomeerde uitstroom gedurende de prognoseperiode gelijk is aan dit gemiddelde wordt een prognose voor de gehele periode 1989-1994 verkregen. Volgens de SVPB heeft ongeveer de helft van de geslaagden voor het Kaderdiploma het Vakdiploma als hoogste vooropleiding. De rest heeft een MBO- of een HBO-opleiding. De geslaagden voor het Kaderdiploma die al een MBO- of een HBO-diploma hebben, worden niet in de herverdeling van de uitstroom uit het regulier voltijdonderwijs betrokken, omdat hun vooropleiding op hetzelfde of op een hoger niveau ligt dan het Kaderdiploma beveiliging (zie hoofdstuk 1). Derhalve worden alleen de geslaagden die het Vakdiploma als vooropleiding hebben in de correctie verdisconteerd.

Voor de prognose van de gediplomeerde uitstroom uit de opleiding tot bewaarder penitentiaire inrichting dient de CWOI-opgave van het aantal geslaagden in de jaren 1989/'90 en 1990/'91 als basis. Door het (te verwachten) aantal geslaagden in de jaren 1988/'89, 1991/'92 en $1992 /$ '93 gelijk te stellen aan het gemiddelde hiervan, ontstaat een prognose van de gediplomeerde uitstroom in de gehele prognoseperiode. Over de vooropleiding van de gediplomeerden zijn geen gegevens bekend. Omdat de opleiding tot hetzelfde opleidingstype (LBO Beveiliging \& Bewaking) behoort als het Basisdiploma beveiliging is de verdeling naar vooropleiding van de geslaagden voor het Basisdiploma geprojecteerd op de prognose van het aantal geslaagden voor de opleiding tot gevangenisbewaarder.

\subsection{De prognose van de gediplomeerde uitstroom uit het in-service-onderwijs}

Het startpunt voor de prognose van de gediplomeerde uitstroom uit het in-service-onderwijs wordt gevormd door de in- en uitstroomcijfers van de GHI en de GHIGV. De GHI-cijfers hebben betrekking op de opleidingen voor verpleegkunde $A$ en Ziekenverzorging in de jaren 1984-1990. De nominale duur van deze opleidingen bedraagt respectievelijk 46 maanden en 30 maanden $^{21}$. Degenen die al in het bezit zijn van een diploma van een andere in-service-opleiding, stromen in het tweede jaar in. Om hiermee rekening te houden, moeten de instroomcijfers van de GHI worden uitgesplitst naar vooropleiding. Daartoe wordt aan het NZi-rapport De arbeidsmarkt voor verpleegkundigen en ziekenverzorgenden: proefproject in het noorden van het land de verdeling van de instroom naar vooropleiding in de periode 1980-1985 ontleend. Deze verdeling wordt geprojecteerd op de instroom in de A- en de ZV-opleidingen in de jaren 19841990. Vervolgens wordt met behulp van de naar vooropleiding verdeelde instroom in de jaren

21. In de jaren 1984 en 1985 bedroeg de nominale opleidingsduur van de ZV-opleiding nog geen 30 maanden, maar 27 maanden. 
1984-1987 en de cijfers over de gediplomeerde uitstroom in de jaren 1988, 1989 en 1990 een gemiddeld rendement voor de A-opleiding berekend. Dit gemiddelde rendement wordt geprojecteerd op de naar vooropleiding verdeelde instroom in de jaren 1987-1990, zodat een prognose van de gediplomeerde uitstroom in de jaren 1991-1993 resulteert, waarbij tegelijkertijd de vooropleiding van de gediplomeerden is bepaald. Vanzelfsprekend wordt in de herverdeling van de uitstroom uit het regulier voltijdonderwijs alleen de gediplomeerde uitstroom verdisconteerd waarbij er sprake is van een niveauverhoging. Op deze wijze worden ook dubbeltellingen als gevolg van de doorstroom van gediplomeerden van de ZV- naar de A-opleiding e.d. voorkomen. Voor de ZV-opleiding wordt een gemiddeld rendement berekend op basis van de naar vooropleiding verdeelde instroom in de jaren 1984-1988 en de cijfers over de gediplomeerde uitstroom in de jaren 1987-1990. Door dit gemiddelde rendement te projecteren op de naar vooropleiding verdeelde instroom in de jaren 1988-1990, resulteert een prognose van de gediplomeerde uitstroom in de jaren 1991 en 1992.

Om voor de A-opleiding tot een prognose voor de gehele prognoseperiode te komen, wordt de prognose van de gediplomeerde uitstroom in de jaren 1991-1993 gecombineerd met de feitelijke uitstroom in de jaren 1989 en 1990. Ten aanzien van de ZV-opleiding wordt er van uit gegaan dat de gediplomeerde uitstroom in 1993 even groot zal zijn als in 1992. Vervolgens kunnen ook hiervoor de prognose van de gediplomeerde uitstroom in de jaren 1991-1993 en de feitelijke uitstroom in de jaren 1989 en 1990 worden gecombineerd tot een prognose voor de gehele prognoseperiode.

De methodiek die voor de prognose van de gediplomeerde uitstroom uit de opleidingen voor verpleegkunde $B$ en $Z$ wordt gehanteerd, komt grotendeels overeen met de werkwijze die bij het opstellen van de prognose voor de A-opleiding is gevolgd. Evenals de A-opleiding duren de B- en de Z-opleidingen nominaal 46 maanden en stromen degenen die al in het bezit zijn van een diploma van een andere in-service-opleiding in het tweede jaar in. In tegenstelling tot de GHIcijfers voor de A-opleiding zijn de GHIGV-cijfers voor de B- en de Z-opleidingen echter uitgesplitst naar vooropleiding 22 . Dit betekent dat geen tussenstap nodig is om op basis van de instroomcijfers voor de jaren 1984-1987 en de cijfers over de uitstroom in de jaren 1988, 1989 en 1990 een gemiddeld rendement te berekenen, dat op de instroom in de jaren 1987-1990 wordt geprojecteerd om een prognose van de gediplomeerde uitstroom in de jaren 1991-1993 te verkrijgen. Evenals bij de A-opleiding ontstaat door combinatie van deze laatste prognose en de feitelijke uitstroom in de jaren 1989 en 1990 een prognose van de gediplomeerde uitstroom uit de $\mathrm{B}$ - en de Z-opleidingen in de gehele prognoseperiode.

\subsection{De prognose van de gediplomeerde uitstroom uit enkele andere niet-reguliere opleidingen}

Naast de prognoses van de gediplomeerde uitstroom uit het onderwijs in de openbare orde en

22. Uitzondering hierop vormen de instroomcijfers van het jaar 1984. Hieraan is de instroomverdeling van 1985 opgelegd. 
veiligheid en het in-service-onderwijs zijn prognoses opgesteld voor enkele andere niet-reguliere opleidingen. Hierbij gaat het om de Rijksacademies van Beeldende Kunsten, de Universiteit voor Bedrijfskunde (Nijenrode) en de opleiding tot registeraccountant van het NIVRA. De prognose van het toekomstige aantal afstudeerders van de Rijksacademies van Beeldende Kunsten is gebaseerd op een door hen gegeven indicatie van het gemiddelde jaarlijkse aantal afstudeerders. Er van uit gaande dat het jaarlijkse aantal afstudeerders in de prognoseperiode op dit gemiddelde zal liggen, wordt een prognose van de gediplomeerde uitstroom verkregen. Omdat de Rijksacademies van Beeldende Kunsten een kopstudie vormen van de Academies voor Beeldende Kunsten, hoeven geen extra berekeningen te worden uitgevoerd om de vooropleiding van de gediplomeerden vast te stellen.

Voor het opstellen van de prognose van de gediplomeerde uitstroom van de Universiteit voor Bedrijfskunde wordt gebruik gemaakt van het Statistisch jaarboek 1990 van het CBS. Daaraan wordt het aantal geslaagden in het studiejaar 1987/' 88 ontleend. Door er van uit te gaan dat het jaarlijkse aantal afstudeerders in de prognoseperiode op het niveau van dat jaar zal blijven liggen, ontstaat een prognose van de gediplomeerde uitstroom op middellange termijn. Er zijn geen gegevens bekend over de vooropleiding van de Nijenrode-studenten. Derhalve wordt voor het bepalen van de vooropleiding van de toekomstige afstudeerders gebruik gemaakt van de herkomstverdeling van de instroom in het reguliere WO, zoals deze op basis van de onderwijsmatrix 1989 kan worden berekend (zie paragraaf 2.4.). Door deze verdeling te projecteren op het verwachte toekomstige aantal afstudeerders ontstaat een prognose van de gediplomeerde uitstroom naar vooropleiding.

Om een prognose op te stellen van de gediplomeerde uitstroom van de NIVRA-opleiding wordt gebruik gemaakt van gegevens uit de jaarverslagen van de NIVRA-opleiding en het NIVRAexamen. Op basis van cijfers over de instroom naar vooropleiding in de jaren 1972/'73$1984 /$ ' 85 en aan het jaarverslag 1989/'90 ontleende informatie over het gemiddelde rendement en de gemiddelde studieduur naar vooropleiding is een berekening gemaakt van het aantal afstudeerders dat in de jaren 1983/'84-1992/'93 mocht worden verwacht indien het rendement en de studieduur gelijk zouden zijn aan de door het NIVRA opgegeven gemiddelden ${ }^{23}$. Het feitelijke aantal afgestudeerden in de jaren 1983/'84-1989/'90 is echter veel groter dan de voor deze jaren berekende aantallen. Op basis hiervan is geconcludeerd dat de berekende aantallen voor de jaren 1990/'91-1992/'93 waarschijnlijk veel te laag zijn. Derhalve worden deze aantallen alleen gebruikt om de verwachte jaarlijkse procentuele groei van de gediplomeerde uitstroom in de jaren 1990/'91-1992/'93 te berekenen. Op basis van het feitelijke aantal afgestudeerden in de jaren 1988/'89 en 1989/'90 en de verwachte groei van het aantal afgestudeerden voor de jaren 1990/'91-1992/'93 wordt vervolgens een prognose van de gediplomeerde uitstroom in de gehele prognoseperiode verkregen, waarin tegelijkertijd de vooropleiding van de gediplomeerden is verdisconteerd.

23. Het jaarverslag 1989/'90 vermeldt een gemiddeld rendement van ongeveer $20 \%$ voor VWO-ers en circa $30 \%$ voor HEAO-ers. De gemiddelde studieduur bedraagt voor VWO-ers 11 tot 12 jaar en voor HEAO-ers 8 à 9 jaar. 
$-30-$

Zoals reeds in hoofdstuk 1 is gezegd, wordt bij het ramen van de instroom van schoolverlaters op de arbeidsmarkt aangesloten bij de wijze waarop de onderwijskwalificaties in de AKT en de EBB worden gecodeerd. Ten aanzien van de NIVRA-opleiding wordt daarbij een bijzondere regel gehanteerd. lemand die de NIVRA-opleiding nog niet heeft afgerond, maar al 8 jaar bezig is met de opleiding en werkzaam is in de accountancy krijgt SOI-code 561. Tot dat moment behoudt men de code van de hoogst voltooide vooropleiding. Voor HEAO-ers die de NIVRA-opleiding volgen is dit niet van belang, omdat zij al SOI-code 561 hebben. Zij krijgen pas SOI-code 661 als ze zijn afgestudeerd. VWO-ers hebben echter SOI-code 401. Hun SOI-code verandert dus op het moment dat ze 8 jaar bezig zijn met de NIVRA-opleiding. Om de prognoses van de verwachte arbeidsvraag en het toekomstig arbeidsaanbod op elkaar af te stemmen, is het derhalve noodzakelijk een prognose op te stellen van het aantal VWO-ers dat in de periode 1989-1994 het moment bereikt dat ze 8 jaar bezig zijn met de NIVRA-opleiding. Daartoe wordt uitgegaan van cijfers over de studiefase (nog studerend, geslaagd of uitgeschreven) van de VWO-ers die in de jaren 1980/'81-1982/'83 zijn ingestroomd. Voor elk van deze jaren is berekend welk deel van de instromers 8 jaar later nog studeert. Op basis van de trendmatige ontwikkeling van deze percentages wordt vervolgens geschat welk deel van de instroom in de jaren 1983/'84$1985 /$ '86 nog zal studeren in de jaren 1990/'91-1992/'93. Door deze prognose samen te voegen met het feitelijke aantal VWO-ers dat in 1981/'82 en 1982/'83 is ingestroomd en 8 jaar later nog studeert, resulteert een prognose van het aantal VWO-ers dat in de periode 19891994 het moment bereikt dat ze 8 jaar bezig zijn met de NIVRA-opleiding. 


\section{DE PROGNOSE VAN DE GEDIPLOMEERDE UITSTROOM UIT HET BE- ROEPSGERICHTE VOLWASSENENONDERWIJS}

\subsection{Inleiding}

In de prognose van de verwachte arbeidsvraag wordt naast de opleidingskwalificaties die in het regulier voltijdonderwijs zijn verkregen, niet alleen rekening gehouden met diploma's die in het regulier deeltijdonderwijs of het niet-regulier onderwijs kunnen worden behaald, maar ook met in de beroepsgerichte volwasseneneducatie verworven kwalificaties. Om de prognose van de verwachte arbeidsvraag en de raming van de toekomstige arbeidsmarktinstroom van schoolverlaters op elkaar af te stemmen, is het dus noodzakelijk een prognose van de gediplomeerde uitstroom uit het beroepsgerichte volwassenenonderwijs op te stellen, waarbij tevens de vooropleiding van de gediplomeerden dient te worden vastgesteld, om het aanbod van gediplomeerden met deze vooropleidingen te kunnen corrigeren voor de doorstroom naar hogere opleidingen.

De prognose van de uitstroom uit het beroepsgerichte volwassenenonderwijs is opgebouwd uit een vijftal deelprognoses:

- een prognose van de gediplomeerde uitstroom uit het deeltijd-AVO, -LBO en -MBO;

- een prognose van de gediplomeerde uitstroom van de Open Universiteit (OU);

- een prognose van de gediplomeerde uitstroom uit het erkend schriftelijk onderwijs (ESO) en het buitenschools mondeling onderwijs (BMO);

- een prognose van de gediplomeerde uitstroom uit bedrijfsopleidingen;

- een prognose van de gediplomeerde uitstroom uit het overige beroepsgerichte volwassenenonderwijs (theologische universiteiten, humanistisch opleidingsinstituut, branche-opleidingen in de gezondheidszorg, bestuursdienstonderwijs, Rijks Opleidingsinstituut, cursorisch ondernemersonderwijs, landbouwvakscholen en scholingsmaatregelen).

Doorgaans zijn deze prognoses gebaseerd op zeer eenvoudige doorrekenmethodieken. Uitgangspunt daarbij is ook geweest om de veranderingen in het kwalificatieprofiel van het arbeidsaanbod niet te overschatten, door het meetellen van erg korte cursussen, niet-beroepsgerichte cursussen, dubbeltellingen e.d. Nadat in paragraaf 5.2. een overzicht is gegeven van het gebruikte datamateriaal, wordt de totstandkoming van de diverse deelprognoses in bovenstaande volgorde beschreven.

\subsection{Datamateriaal}

Bij de raming van de toekomstige gediplomeerde uitstroom uit het beroepsgerichte volwassenenonderwijs is gebruik gemaakt van het volgende datamateriaal:

1. de Statistiek van het vwo, havo en mavo 1989/'90 van het CBS;

2. de Statistiek van het lager beroepsonderwijs 1989/' 90 van het CBS;

3. de publikatie Volwasseneneducatie, statistisch overzicht 1989 van het CBS (Centraal Bureau voor de Statistiek, 1991b); 
4. de Statistiek van het middelbaar beroepsonderwijs 1989/'90 van het CBS;

5. de onderwijsmatrix 1989 van het CBS;

6. WORSA 1990;

7. een CBS-mededeling betreffende de studenten aan de OU per 1 november 1988 (Centraal Bureau voor de Statistiek, 1989);

8. de publikatie Volwasseneneducatie; particulier onderwijs, 1989 van het CBS (Centraal Bureau voor de Statistiek, 1991a);

9. de publikatie Bedrijfsopleidingen in Nederland 1986 van het CBS (Centraal Bureau voor de Statistiek, 1988);

10. de publikatie Volwasseneneducatie; beroepsbegeleidend onderwijs en vormingswerk/cursorisch ondernemersonderwijs 1988/'89 van het CBS (Centraal Bureau voor de Statistiek, 1990f);

11. onderwijsgegevens uit het Statistisch jaarboek 1990 van het CBS;

12. de HBO-werktabellen die het CBS gebruikt bij de samenstelling van de onderwijsmatrix;

13. opleidingsgegevens van het Centraal Bureau voor de Arbeidsvoorziening.

De bronnen 1, 2, 4, 5, 6 en 12 zijn reeds in hoofdstuk 2 beschreven. Aan het overige datamateriaal zal hieronder kort aandacht worden gegeven.

De publikatie Volwasseneneducatie, statistisch overzicht van het CBS is een overzichtspublikatie met kerncijfers over het volwassenenonderwijs. De gepresenteerde gegevens bestrijken vrijwel alle vormen van volwasseneneducatie en hebben hoofdzakelijk betrekking op deelnemersaantallen. Van deze gegevens is met name gebruik gemaakt bij het opstellen van de prognoses van de gediplomeerde uitstroom uit het deeltijd-LBO, de OU, het ESO, het BMO, de branche-opleidingen in de gezondheidszorg ${ }^{24}$, het bestuursdienstonderwijs en het Rijks Opleidingsinstituut (ROI).

De CBS-mededeling betreffende de studenten aan de OU bevat onder meer gegevens over het voorlopig studieplan, de leeftijd en de hoogst voltooide vooropleiding van de ingeschrevenen. De peildatum van de gegevens is 1 november 1988. De cijfers zijn gebruikt voor het vaststellen van de vooropleiding van de toekomstige afstudeerders van de OU.

De publikatie Volwasseneneducatie; particulier onderwijs van het CBS heeft betrekking op het ESO en het BMO. Er wordt onder andere inzicht gegeven in het aantal cursisten naar onderwijsniveau en -sector (voortgezet onderwijs, lagere trap/agrarisch, voortgezet onderwijs, hogere trap/technisch, hoger onderwijs, eerste fase/economie, etc.) en cursusduur. Deze cijfers vormen het uitgangspunt voor de prognose van de gediplomeerde uitstroom uit het ESO en het BMO.

De prognose van de gediplomeerde uitstroom uit bedrijfsopleidingen steunt op de publikatie Bedrijfsopleidingen in Nederland. Deze publikatie geeft onder meer informatie over het aantal

24. Onder branche-opleidingen in de gezondheidszorg worden verstaan alle gezondheidszorgopleidingen die niet onder het regulier onderwijs, het in-service-onderwijs, het erkend schriftelijk onderwijs of het buitenschools mondeling onderwijs vallen. 
deelnemers aan interne bedrijfsopleidingen naar werkterrein (horeca, juridisch, management, etc.) en duur van de opleiding. Daarnaast bevat de publikatie cijfers over het aantal deelnemers aan externe branche-opleidingen. De gegevens hebben betrekking op het jaar 1986 .

De publikatie Volwasseneneducatie; beroepsbegeleidend onderwijs en vormingswerk/cursorisch ondernemersonderwijs wordt gebruikt voor de prognose van de gediplomeerde uitstroom uit het cursorisch ondernemersonderwijs en de landbouwvakscholen. Wat betreft het cursorisch ondernemersonderwijs gaat het hierbij met name om instroom-, deelnemers- en geslaagdenaantallen. Ten aanzien van de landbouwvakscholen is gebruik gemaakt van de aantallen eerstejaarsleerlingen naar vakrichting (bosbouw en cultuurtechniek, land- en tuinbouw, etc.) en de verdeling van de instroom naar vooropleiding.

Aan het Statistisch jaarboek 1990 is het aantal geslaagden voor het afsluitend examen van de theologische universiteiten in het jaar 1987/'88 ontleend. Dit aantal vormt de basis van de prognose van de toekomstige gediplomeerde uitstroom van deze instellingen.

Om rekening te houden met de invloed van scholingsmaatregelen (Centra voor Beroepsoriëntatie en Beroepsoefening, Centra voor (Administratieve) Vakopleiding van Volwassenen en Kaderregeling Scholing), zijn door het Centraal Bureau voor de Arbeidsvoorziening gegevens verstrekt over het aantal mensen dat in 1989 een door de Arbeidsvoorzieningsorganisatie (ARBVO) gecoördineerde opleiding succesvol heeft afgerond. Dit aantal is uitgesplitst naar leeftijd en richting (metaal, bouw, administratie, etc.). Op basis hiervan is de prognose van de toekomstige gediplomeerde uitstroom uit de ARBVO-opleidingen opgesteld.

Naast de publikatie Vo/wasseneneducatie, statistisch overzicht is bij het opstellen van de prognose van de gediplomeerde uitstroom uit het deeltijd-AVO, -LBO en -MBO gebruik gemaakt van de Statistiek van het vwo, havo en mavo, de Statistiek van het lager beroepsonderwijs, de Statistiek van het middelbaar beroepsonderwijs en de onderwijsmatrix. Voor de prognose van het toekomstig aantal afstudeerders van de OU zijn de gegevens uit het statistisch overzicht en de CBS-mededeling aangevuld met cijfers uit WORSA 1990.

Om tot een prognose van de gediplomeerde uitstroom uit het ESO en het BMO te komen, is gebruik gemaakt van data uit de publikaties Volwasseneneducatie; particulier onderwijs en Volwasseneneducatie, statistisch overzicht. Daarnaast is gebruik gemaakt van de onderwijsmatrix. Ook bij de prognose van de gediplomeerde uitstroom uit bedrijfsopleidingen heeft de onderwijsmatrix dienst gedaan als aanvulling op de data uit de desbetreffende CBS-publikatie.

Bij het opstellen van de prognose van het toekomstig aantal afstudeerders van het humanistisch opleidingsinstituut is uitgegaan van het aantal geslaagden volgens de CBS-werktabellen met betrekking tot het HBO. De prognose van de gediplomeerde uitstroom uit de branche-opleidingen in de gezondheidszorg is gebaseerd op een combinatie van data uit de publikatie Volwasseneneducatie, statistisch overzicht en de onderwijsmatrix. Ditzelfde geldt voor de prognoses ten aanzien van het bestuursdienstonderwijs en het ROI. 
De prognoses van de toekomstige gediplomeerde uitstroom uit het cursorisch ondernemersonderwijs en de landbouwvakscholen zijn tot stand gebracht met behulp van gegevens uit de publikatie Volwasseneneducatie; beroepsbegeleidend onderwijs en vormingswerk/cursorisch ondernemersonderwijs en de onderwijsmatrix.

\subsection{De prognose van de gediplomeerde uitstroom uit het deeltijd-AVO, -LBO en - MBO}

Bij het opstellen van de prognose van de gediplomeerde uitstroom uit het deeltijd-AVO (MAVO, HAVO en VWO) wordt uitgegaan van de aantallen geslaagden voor het volledig examen en de door middel van certificaten behaalde diploma's in het jaar 1989. Deze aantallen zijn ontleend aan de Statistiek van het vwo, havo en mavo 1989/'90. Door er van uit te gaan dat het jaarlijkse aantal geslaagden gedurende de rest van de prognoseperiode op het niveau van 1989 zal blijven liggen, wordt een prognose verkregen van de gediplomeerde uitstroom uit de drie schoolsoorten in het deeltijd-AVO. Naar alle waarschijnlijkheid zullen niet alle gediplomeerden de intentie hebben zich na het afsluiten van hun opleiding aan te bieden op de arbeidsmarkt. Derhalve wordt voor elk van de drie schoolsoorten een correctie op de prognose van de gediplomeerde uitstroom aangebracht. Daarbij wordt eenvoudigheidshalve aangenomen dat de opleiding alleen beroepsgericht is voor geslaagden die jonger zijn dan 30 jaar. De berekening van de leeftijdscorrectiefactoren geschiedt op basis van de leeftijdsverdeling van de leerlingen in het studiejaar 1989/'90. Door de prognoses van de gediplomeerde uitstroom te vermenigvuldigen met de leeftijdscorrectiefactoren, resulteert voor elk van de drie schoolsoorten een prognose van de uitstroom van gediplomeerden naar de arbeidsmarkt.

Om het verwachte aantal instromers op de arbeidsmarkt in mindering te brengen op het arbeidsaanbod in de opleidingscategorie waartoe hun hoogst voltooide vooropleiding behoort, wordt er van uit gegaan dat de gediplomeerde MAVO-ers allen voorheen slechts basisonderwijs hebben genoten. Ten aanzien van de HAVO-ers wordt aangenomen dat zij allen in het bezit zijn van een MAVO-diploma. De VWO-ers worden geacht reeds eerder een HAVO-diploma te hebben behaald.

De prognose van de gediplomeerde uitstroom uit het deeltijd-LBO bestaat uit een prognose van de gediplomeerde uitstroom uit het lager nautisch onderwijs (LNO) in deeltijdse vorm en een prognose van de gediplomeerde uitstroom uit het lager agrarisch onderwijs (LAO) in deeltijdse vorm. De methodiek die bij de prognose van de gediplomeerde uitstroom uit het deeltijd-LBO is gebruikt, lijkt sterk op de werkwijze die bij het opstellen van de prognoses voor het deeltijd-AVO is gehanteerd. Aan de Statistiek van het lager beroepsonderwijs 1989/'90 zijn de aantallen geslaagden bij het LNO naar studierichting (radarnavigatie binnenvaart, schipper binnenvaart, visbewerken en fileren, etc.) en de aantallen geslaagden bij de basiscursussen in het LAO naar soort cursus (aanleg en onderhoud, grondtaxatie, klimtechnieken in bomen, etc.) in het jaar 1989 ontleend. Er van uit gaande dat het jaarlijkse aantal geslaagden in de rest van de prognoseperiode op het niveau van 1989 zal blijven liggen, worden prognoses van de gediplomeerde uitstroom uit het deeltijd-LNO (naar studierichting) en het deeltijd-LAO (naar soort 
cursus) verkregen. Evenals bij het deeltijd-AVO wordt hierop een beroepsgerichtheidscorrectie aangebracht. Voor het deeltijd-LNO gebeurt dit op grond van de leeftijdsverdeling van de leerlingen in het jaar 1989/'90. Voor het LAO wordt de leeftijdsverdeling van de leerlingen in het jaar 1988/'89 gebruikt. Beide verdelingen zijn ontleend aan de CBS-publikatie Volwasseneneducatie, statistisch overzicht 1989. Bij de berekening van de leeftijdscorrectiefactoren wordt er van uit gegaan dat de opleiding alleen beroepsgericht is voor geslaagden die jonger zijn dan 30 jaar.

Op de prognose van de gediplomeerde uitstroom uit het deeltijd-LAO wordt nog een extra beroepsgerichtheidscorrectie aangebracht, omdat het hierbij hoofdzakelijk om kortlopende cursussen gaat. Er wordt aangenomen dat slechts $10 \%$ van de cursussen beroepsgericht is en tot een substantiële verandering van het kwalificatieprofiel van het arbeidsaanbod leidt. Door vermenigvuldiging van de prognoses van de gediplomeerde uitstroom met de correctiefactoren, ontstaat zowel voor het deeltijd-LNO als voor het deeltijd-LAO een prognose van de uitstroom van gediplomeerden naar de arbeidsmarkt. Van de gediplomeerden wordt verondersteld dat zij allen basisonderwijs als hoogste vooropleiding hebben.

De prognose van de gediplomeerde uitstroom uit het deeltijd-MBO is gebaseerd op de geslaagdenaantallen in het jaar (1988/)1989. Deze aantallen zijn gedifferentieerd naar schoolsoort (middelbaar agrarisch onderwijs, middelbaar technisch onderwijs, middelbaar laboratoriumonderwijs, middelbaar economisch en administratief onderwijs en middelbaar dienstverlenings- en gezondheidszorgonderwijs) en studierichting ${ }^{25}$ en afkomstig uit de Statistiek van het middelbaar beroepsonderwijs 1989/'90. Ook hierbij wordt er van uit gegaan dat het jaarlijkse aantal geslaagden in de periode 1990-1994 op het niveau van 1989 zal liggen en dat de opleidingen alleen beroepsgericht zijn voor geslaagden die jonger zijn dan 30 jaar. De leeftijdscorrectiefactoren worden berekend op basis van de aan de Statistiek van het middelbaar beroepsonderwijs ontleende leeftijdsverdeling van de leerlingen in het jaar 1989/' $90^{26}$. Deze verdelingen zijn gedifferentieerd naar schoolsoort. Door vermenigvuldiging van de prognose van het verwachte aantal geslaagden ontstaat voor elk van de schoolsoorten in het deeltijd-MBO een prognose van de uitstroom van gediplomeerden naar de arbeidsmarkt. Omdat er bij het MAO sprake is van kortlopende cursussen is nog eens een extra correctie voor de beroepsgerichtheid en de duur van de opleidingen aangebracht, waardoor slechts $10 \%$ van de geslaagden die jonger zijn dan 30 jaar als gediplomeerde uitstroom naar de arbeidsmarkt wordt beschouwd.

De vooropleiding van de verwachte gediplomeerde uitstroom uit het middelbaar technisch onderwijs (MTO) en het middelbaar dienstverlenings- en gezondheidszorgonderwijs (MDGO) in deeltijdse vorm wordt eveneens bepaald met behulp van cijfers uit de Statistiek van het

25. De geslaagden bij het middelbaar economisch en administratief onderwijs (MEAO) zijn niet uitgesplitst naar studierichting. De geslaagden bij het middelbaar agrarisch onderwijs (MAO) zijn uitgesplitst naar cursus (actuele rundveehouderij. gewasbescherming, grasland voederwinning, etc.).

26. Voor het MAO is de leeftijdsverdeling in het jaar $1988 /{ }^{\prime} 89$ gebruikt. 
middelbaar beroepsonderwijs 1989/'90. Daarbij gaat het met name om de verdeling van de instroom naar vooropleiding in het jaar 1989/'90. Deze verdeling wordt geprojecteerd op de prognose van de gediplomeerde uitstroom naar de arbeidsmarkt. Hierdoor ontstaat zowel voor het deeltijd-MTO als het deeltijd-MDGO een prognose van de instroom op de arbeidsmarkt naar hoogst voltooide vooropleiding. Ten aanzien van het middelbaar laboratoriumonderwijs wordt aangenomen dat alle gediplomeerden over een LTO-diploma beschikken. De prognose van de arbeidsmarktinstroom van gediplomeerden van het deeltijd-MAO en het deeltijd-MEAO wordt naar vooropleiding verbijzonderd met behulp van de instroomverdeling in de voltijdse variant van beide schoolsoorten. Deze verdeling is ontleend aan de onderwijsmatrix 1989 (zie paragraaf 2.4.).

\subsection{De prognose van de gediplomeerde uitstroom van de OU}

Voor het opstellen van de prognose van de gediplomeerde uitstroom van de OU wordt uitgegaan van gegevens uit de publikatie Volwasseneneducatie, statistisch overzicht 1989. Daarbij gaat het met name om het naar leerstofgebied (rechtswetenschappen, economische wetenschappen, technische wetenschappen, etc.) uitgesplitste aantal studenten dat in 1989 aan een diplomaprogramma is begonnen. Zo gauw de OU-studenten een module van het diplomaprogramma behalen, kan hun opleidingskwalificatie in principe veranderen. Hoewel het niveau van een module lager is dan het niveau van de propaedeuse in het gewone WO, wordt er van uit gegaan dat het gemiddelde jaarlijkse aantal OU-studenten dat een module behaalt kan worden geschat door per leerstofgebied het aantal eerstejaars-studenten in 1989 te vermenigvuldigen met het gemiddeld propaedeuserendement van de eerstejaars-cohorten in de corresponderende studierichtingen van het gewone $\mathrm{WO}^{27}$. Teneinde een prognose voor de gehele periode 1989-1994 te verkrijgen, wordt verondersteld dat het jaarlijkse aantal studenten dat in deze periode een module behaald gelijk is aan het geschatte gemiddelde.

Ook op de OU-prognose wordt een beroepsgerichtheidscorrectie aangebracht. Er wordt van uit gegaan dat het behalen van een module alleen effect heeft op het arbeidsaanbod indien een student jonger is dan 30 jaar. De noodzakelijke correctiefactor wordt berekend op basis van de leeftijdsverdeling van de OU-studenten die in 1989 een diplomaprogramma volgen. De verdeling is ontleend aan het statistisch overzicht volwasseneneducatie.

Om de OU-prognose naar vooropleiding te verdelen, wordt gebruik gemaakt van een CBSmededeling betreffende de OU-studenten op 1 november 1988. Deze bevat onder meer gegevens over de hoogst voltooide vooropleiding van de ingeschrevenen. $\mathrm{Er}$ van uit gaande dat de op basis hiervan te berekenen verdeling naar vooropleiding ook van toepassing is op de toekomstige afstudeerders, kunnen deze laatste in mindering worden gebracht op het verwachte arbeidsaanbod in de opleidingscategorie waartoe hun vooropleiding behoort.

27. Deze rendementscijfers zijn ontleend aan WORSA 1990 en hebben betrekking op de eerstejaars-cohorten van de studiejaren 1982/' 83 en 1983/' 84. 


\subsection{De prognose van de gediplomeerde uitstroom uit het ESO en het BMO}

Bij het opstellen van de prognose van de gediplomeerde uitstroom uit het ESO en het BMO wordt uitgegaan van de aantallen cursisten naar onderwijsniveau en - sector, zoals deze staan vermeld in de publikatie Volwasseneneducatie; particulier onderwijs, 1989. Allereerst wordt voor de cursussen die 6 maanden of langer duren ${ }^{28}$ een schatting gemaakt van het gemiddelde jaarlijkse aantal examenkandidaten. Hierbij wordt er van uit gegaan dat het gemiddelde jaarlijkse aantal examenkandidaten van cursussen die 7 tot 12 maanden duren gelijk is aan het aantal cursisten in 1989. Het gemiddelde jaarlijkse aantal examenkandidaten van cursussen die 13 tot 24 maanden duren wordt geschat door het aantal cursisten in 1989 te delen door de gemiddelde opleidingsduur (1,5 jaar). Het gemiddelde jaarlijkse aantal examenkandidaten van cursussen die 25 maanden of langer duren wordt benaderd door het aantal cursisten in 1989 te delen door de factor $3^{29}$. Door het slagingspercentage op $50 \%$ te stellen, wordt met behulp van het geschatte gemiddelde jaarlijkse aantal examenkandidaten een schatting verkregen van het gemiddelde jaarlijkse aantal geslaagden van de ESO- en de BMO-cursussen. Er van uit gaande dat het jaarlijkse aantal geslaagden in de periode 1989-1994 gelijk is aan dit gemiddelde, wordt een prognose van de gediplomeerde uitstroom uit het ESO en het BMO verkregen.

Om te voorkomen dat er een overschatting optreedt van het aantal mensen dat op basis van een schriftelijke of mondelinge cursus zich met een ander kwalificiatieprofiel op de arbeidsmarkt kan aanbieden, wordt op de prognose een dubbele correctie aangebracht. Ten eerste wordt aangenomen dat de cursussen alleen beroepsgericht zijn voor geslaagden die jonger zijn dan 30 jaar. Omdat over de ESO- en de BMO-cursisten geen leeftijdsgegevens beschikbaar zijn, wordt de leeftijdscorrectie uitgevoerd met de factor die bij de OU-prognose is berekend. Ten tweede is er bij het ESO en het BMO sprake van cursussen, die doorgaans slechts een gering aantal uren per week werk met zich meebrengen. Derhalve wordt slechts $10 \%$ van het verwachte aantal geslaagden dat jonger is dan 30 jaar in de toekomstige arbeidsmarktinstroom naar opleidingstype verdisconteerd.

Bij de vaststelling van de vooropleiding van de geslaagde ESO- en BMO-cursisten wordt als volgt te werk gegaan. Van de geslaagden voor cursussen op het niveau van de lagere trap van het voortgezet onderwijs (LBO/MAVO) wordt aangenomen dat zij basisonderwijs als hoogst voltooide vooropleiding hebben. Ten aanzien van de geslaagden voor cursussen op HAVO/VWOniveau wordt verondersteld dat zij een MAVO-diploma hebben behaald. Voor de bepaling van de

28. De cursussen die korter dan 6 maanden duren worden buiten beschouwing gelaten, omdat het $C B S$ in de AKT en de EBB, behoudens enkele uitzonderingen, alleen cursussen registreert die in voltijdse equivalenten 6 maanden of langer duren. Derhalve zijn de cursussen die korter dan 6 maanden duren niet verdisconteerd in de prognose van de verwachte arbeidsvraag. Teneinde de prognoses van vraag en aanbod op elkaar af te stemmen, dienen de korte cursussen dus ook buiten beschouwing te blijven in de raming van het toekomstig arbeidsaanbod.

29. Er wordt van uit gegaan dat ESO- en BMO-cursussen niet langer dan 4 jaar duren. 
vooropleiding van de geslaagden voor cursussen op MBO-niveau wordt gebruik gemaakt van de verdeling van de instroom in het voltijd-MBO naar schoolsoort van herkomst, zoals deze op basis van de onderwijsmatrix kan worden berekend (zie paragraaf 2.4.). Analoog hieraan wordt de vooropleiding van geslaagden voor cursussen op het niveau van de eerste fase van het HBO bepaald met behulp van de verdeling van de instroom in het voltijd-HBO. De geslaagden voor cursussen op het niveau van de tweede fase van het $\mathrm{HBO}$ worden verondersteld de akte Middelbaar Onderwijs-A (MO-A) als vooropleiding te hebben.

\subsection{De prognose van de gediplomeerde uitstroom uit bedrijfsopleidingen}

De prognose van de gediplomeerde uitstroom uit bedrijfsopleidingen steunt op gegevens uit de publikatie Bedrijfsopleidingen in Nederland 1986. Op grond van het aantal deelnemers aan interne bedrijfsopleidingen ${ }^{30}$ en externe branche-opleidingen in het jaar 1986 wordt een schatting gemaakt van het gemiddelde jaarlijkse aantal cursisten dat een bedrijfsopleiding succesvol afrondt. Daarbij wordt er van uit gegaan dat ook het merendeel van de cursussen die langer dan 10 dagen duren geen invloed kan hebben op het kwalificatieniveau van het arbeidsaanbod. Verondersteld wordt dat slechts bij $10 \%$ van de cursussen sprake is van een niveauverhogende cursus met een substantieel tijdsbeslag en dat de helft van de cursisten deze opleidingen met succes afrondt.

Aan de CBS-publikatie betreffende de bedrijfsopleidingen in Nederland kan tevens de verdeling van de deelnemers aan interne bedrijfsopleidingen naar terrein van opleiding worden ontleend. Op basis hiervan kan de schatting van het gemiddelde jaarlijkse aantal cursisten dat een interne bedrijfsopleiding succesvol afrondt naar SOI-opleidingstype worden gedifferentieerd. Van de deelnemers aan externe branche-opleidingen is het terrein van opleiding niet bekend. Derhalve wordt de verdeling van de deelnemers aan interne bedrijfsopleidingen naar terrein van opleiding geprojecteerd op de schatting van het gemiddelde jaarlijkse aantal cursisten dat een externe branche-opleiding succesvol afrondt, zodat ook voor deze opleidingen een schatting naar SOIopleidingstype wordt verkregen.

De prognose van de gediplomeerde uitstroom uit de interne bedrijfsopleidingen en de externe branche-opleidingen komt tot stand door er van uit te gaan dat het jaarlijkse aantal cursisten dat een opleiding succesvol afrondt in de periode 1989-1994 gelijk zal zijn aan het geschatte gemiddelde. Van de succesvolle cursisten van bedrijfsopleidingen op LBO-niveau wordt aangenomen dat zij basisonderwijs als hoogste vooropleiding hebben. De vooropleiding van de cursisten die een bedrijfsopleiding op MBO- of HBO-niveau hebben afgerond, wordt bepaald op basis van de naar schoolsoort van herkomst verdeelde instroom in de voltijdse varianten van het MBO en het HBO in het jaar 1989/'90. De instroomverdelingen zijn berekend uit de onderwijsmatrix (zie paragraaf 2.4.).

30. Van de interne bedrijfsopleidingen worden alleen de opleidingen die langer dan 10 dagen duren in de analyse betrokken. 


\subsection{De prognose van de gediplomeerde uitstroom uit het overige beroepsgerichte volwassenenonderwijs}

De prognose van de gediplomeerde uitstroom uit het overige beroepsgerichte volwassenenonderwijs heeft betrekking op de volgende opleidingen:

- theologische universiteiten;

- humanistisch opleidingsinstituut;

- branche-opleidingen in de gezondheidszorg;

- bestuursdienstonderwijs;

- ROI;

- cursorisch ondernemersonderwijs;

- landbouwvakscholen;

- scholingsmaatregelen.

De prognose van de gediplomeerde uitstroom van de theologische universiteiten is opgesteld op basis van cijfers uit het Statistisch jaarboek 1990 van het CBS. Daarbij gaat het met name om het aantal geslaagden voor het afsluitend examen in het studiejaar 1987/'88. Door er van uit te gaan dat het jaarlijkse aantal afstudeerders in de periode 1989-1994 op hetzelfde niveau zal blijven liggen, resulteert een raming van de toekomstige gediplomeerde uitstroom op middellange termijn. Er zijn geen gegevens beschikbaar over de vooropleiding van de studenten aan de theologische universiteiten. Derhalve wordt de vooropleiding van de toekomstige afstudeerders bepaald met behulp van de herkomstverdeling van de instroom in het reguliere WO, zoals deze op basis van de onderwijsmatrix 1989 kan worden berekend (zie paragraaf 2.4.). Door deze verdeling te projecteren op het verwachte toekomstige aantal afstudeerders, ontstaat een naar vooropleiding gedifferentieerde prognose van de gediplomeerde uitstroom.

Bij het opstellen van de prognose van de gediplomeerde uitstroom van het humanistisch opleidingsinstituut is gebruik gemaakt van de werktabellen die het CBS samenstelt ten behoeve van de constructie van de onderwijsmatrix. Aan deze tabellen is het aantal afgestudeerden van het humanistisch opleidingsinstituut in het jaar 1988/'89 ontleend. Aannemende dat het jaarlijkse aantal afstudeerders in de rest van de prognoseperiode op het niveau van 1988/' 89 zal blijven liggen, wordt een prognose van de gediplomeerde uitstroom in de gehele periode 19891994 verkregen. Ook van de studenten aan het humanistisch opleidingsinstituut zijn geen vooropleidingsgegevens bekend. Derhalve wordt de prognose van de toekomstige gediplomeerde uitstroom naar vooropleiding gedifferentieerd met behulp van de herkomstverdeling van de instroom in het voltijd-HBO. Deze verdeling is berekend op basis van de onderwijsmatrix (zie paragraaf 2.4.).

De prognose van de gediplomeerde uitstroom uit de branche-opleidingen in de gezondheidszorg (exclusief verpleegkunde $A / B / Z$ en Ziekenverzorging) is gebaseerd op een combinatie van data uit de publikatie Volwasseneneducatie, statistisch overzicht 1989 en de onderwijsmatrix. In de eerstgenoemde publikatie zijn gegevens opgenomen over het aantal geslaagden voor de branche-opleidingen in de gezondheidszorg op respectievelijk LBO-, MBO-, HBO- en WO-niveau. 
Deze aantallen hebben betrekking op het jaar 1989. Door er van uit te gaan dat het jaarlijkse aantal geslaagden gedurende de rest van de prognoseperiode op het niveau van 1989 zal blijven liggen, resulteert voor elk van de branche-opleidingen een prognose van de gediplomeerde uitstroom in de gehele periode 1989-1994. Daar mag worden verwacht dat niet alle geslaagden van deze opleidingen zich op de arbeidsmarkt zullen aanbieden, wordt hiervoor een correctie op de prognose van de gediplomeerde uitstroom aangebracht. Daarbij wordt eenvoudigheidshalve aangenomen dat de opleidingen alleen van belang zijn voor de beroepsuitoefening van geslaagden die jonger zijn dan 30 jaar. De leeftijdscorrectiefactor voor de geslaagden van de brancheopleidingen op LBO-niveau wordt berekend op basis van de leeftijdsverdeling van de deelnemers aan het regulier deeltijd-LBO in het jaar 1989/'90. De leeftijdscorrectiefactoren voor de geslaagden van de branche-opleidingen op MBO-, HBO- en WO-niveau worden berekend aan de hand van de leeftijdsverdelingen van de deelnemers aan respectievelijk het deeltijd-MDGO, het deeltijd-HGZO en het deeltijd-WO. De leeftijdsverdelingen hebben betrekking op het jaar $1989 / 90$ en zijn ontleend aan de overzichtspublikatie over de volwasseneneducatie in het jaar 1989.

Over de vooropleiding van de geslaagden voor de branche-opleidingen in de gezondheidszorg zijn geen gegevens beschikbaar. Derhalve wordt verondersteld dat de geslaagden voor de opleidingen op LBO-niveau allen slechts basisonderwijs als hoogste vooropleiding hebben. De vooropleiding van de toekomstige geslaagden voor de opleidingen op MBO-, HBO- en WOniveau wordt bepaald met behulp van de herkomstverdeling van de instroom in respectievelijk het voltijd-MDGO, het voltijd-HGZO en het voltijd-WO. Deze verdelingen zijn berekend op basis van de onderwijsmatrix 1989 (zie paragraaf 2.4.).

Ook de prognose van de gediplomeerde uitstroom uit het bestuursdienstonderwijs steunt op cijfers uit de overzichtspublikatie betreffende de volwasseneneducatie in 1989. Daarbij gaat het met name om het aantal examenkandidaten voor gereglementeerde opleidingen. Dit aantal wordt gehanteerd als schatting van het gemiddelde jaarlijkse aantal examenkandidaten. Door het slagingspercentage op $50 \%$ te stellen, wordt een benadering verkregen van het gemiddelde jaarlijkse aantal geslaagden in het bestuursdienstonderwijs. Er van uit gaande dat het jaarlijkse aantal geslaagden gedurende de rest van de prognoseperiode op het niveau van het geschatte gemiddelde zal liggen, resulteert een prognose van de gediplomeerde uitstroom uit het bestuursdienstonderwijs voor de gehele periode 1989-1994.

Op de prognose van de gediplomeerde uitstroom uit het bestuursdienstonderwijs wordt een dubbele 'beroepsgerichtheidscorrectie' aangebracht. De manier waarop dit is gebeurd is identiek aan de wijze waarop de beroepsgerichtheidscorrectie op de prognose van de gediplomeerde uitstroom uit het ESO en het BMO is uitgevoerd (zie paragraaf 5.5.). De vooropleiding van de verwachte toekomstige arbeidsmarktinstroom van de gediplomeerden is bepaald aan de hand van de aan de onderwijsmatrix 1989 ontleende herkomstverdeling van de instroom in het voltijd-MBO in het jaar 1989/'90 (zie paragraaf 2.4.). 
Voor de prognose van de gediplomeerde uitstroom van het ROI wordt uitgegaan van de aantallen deelnemers aan ROI-cursussen naar cursussoort (informatica-opleidingen, organisatieadvies-opleidingen, personeelsbeleid en management, etc.) in 1989 (bron: Volwasseneneducatie, statistisch overzicht 1989). Uitgaande van een opleidingsduur van 1 jaar en een slagingspercentage van $50 \%$ wordt op basis van deze deelnemersaantallen een schatting gemaakt van het gemiddelde jaarlijkse aantal geslaagden naar cursussoort. Door aan te nemen dat het jaarlijkse aantal geslaagden gedurende de prognoseperiode gelijk zal zijn aan het geschatte gemiddelde, ontstaat een prognose van de gediplomeerde uitstroom van het ROI. Ook hierop wordt de dubbele beroepsgerichtheidscorrectie aangebracht die reeds bij de prognose van de gediplomeerde uitstroom uit het ESO en het BMO is toegepast.

De ROI-opleidingen liggen op MBO- en HBO-niveau. De vooropleiding van de gediplomeerden van de ROI-opleidingen wordt derhalve bepaald met behulp van de herkomstverdeling van de instroom (berekend op basis van de onderwijsmatrix) in respectievelijk het voltijd-MBO en het voltijd-HBO.

Het datamateriaal dat voor de prognose van de gediplomeerde uitstroom uit het cursorisch ondernemersonderwijs is gebruikt, is afkomstig uit de publikatie Volwasseneneducatie; beroepsbegeleidend onderwijs en vormingswerk/cursorisch ondernemersonderwijs 1988/'89. Daarbij wordt het aantal geslaagden in 1988 beschouwd als een schatting van het te verwachten gemiddelde jaarlijkse aantal geslaagden gedurende de prognoseperiode. Op die manier ontstaat een prognose van de gediplomeerde uitstroom uit het cursorisch ondernemersonderwijs in de periode 1989-1994. Hierop wordt een beroepsgerichtheidscorrectie aangebracht met behulp van de leeftijdsverdeling van de deelnemers aan het cursorisch ondernemersonderwijs op 1 november 1988. Daarbij wordt er van uit gegaan dat de cursussen alleen beroepsgericht zijn voor gediplomeerden die jonger zijn dan 30 jaar.

Om de prognose van de gediplomeerden van het cursorisch ondernemersonderwijs die zich met hun opleiding op de arbeidsmarkt begeven naar vooropleiding te differentiëren, wordt gebruik gemaakt van gegevens over de hoogst behaalde vooropleiding van de instromers in het cursorisch ondernemersonderwijs in 1988. Op basis hiervan wordt een instroomverdeling berekend die vervolgens op de prognose wordt geprojecteerd.

Om tot een prognose van de gediplomeerde uitstroom uit de landbouwvakscholen te komen, wordt eveneens gebruik gemaakt van de publikatie Volwasseneneducatie; beroepsbegeleidend onderwijs en vormingswerk/cursorisch ondernemersonderwijs 1988/'89. Daarbij vormt het naar vakrichting uitgesplitste aantal eerstejaars-leerlingen in het studiejaar 1988/'89 het uitgangspunt. Dit aantal wordt beschouwd als een schatting van de gemiddelde jaarlijkse instroom. Evenals bij de prognose van de gediplomeerde uitstroom uit het voltijd-KMBO en het Leerlingwezen (zie paragraaf 3.3.) wordt het gemiddelde rendement op $70 \%$ geschat. Door de schatting van de gemiddelde jaarlijkse instroom te vermenigvuldigen met het rendementspercentage wordt een indicatie van het gemiddelde jaarlijkse aantal geslaagden verkregen. Door er van uit te gaan dat het jaarlijkse aantal geslaagden gedurende de prognoseperiode gelijk zal zijn aan het 
geschatte gemiddelde, ontstaat een prognose van de gediplomeerde uitstroom uit de landbouwvakscholen in de periode 1989-1994. Op deze prognose wordt vervolgens een beroepsgerichtheidscorrectie aangebracht. Daarbij wordt er van uit gegaan dat de opleidingen aan de landbouwvakscholen alleen van belang zijn voor de toekomstige beroepsuitoefening van de gediplomeerden die rechtstreeks afkomstig zijn uit het voltijdonderwijs. De desbetreffende correctiefactor wordt berekend op basis van de naar activiteit (onderwijs, buitenland, geen onderwijs, etc.) in het voorafgaande jaar (1987/'88) verdeelde instroom in 1988/'89. Tevens kan aan de hand van deze verdeling de vooropleiding van de gediplomeerde uitstroom naar de arbeidsmarkt worden bepaald, omdat van degenen die in 1987/' 88 voltijdonderwijs volgden de schoolsoort van herkomst bekend is.

Het laatste onderdeel van de prognose van de gediplomeerde uitstroom uit het beroepsgerichte volwassenenonderwijs is de prognose van het aantal mensen dat een opleiding in het kader van de scholingsmaatregelen van de Arbeidsvoorzieningsorganisatie succesvol afrondt. Voor het opstellen van deze prognose is door het Centraal Bureau voor de Arbeidsvoorziening een opgave verstrekt van het aantal mensen dat in 1989 een ARBVO-opleiding met een diploma heeft afgesloten. Door er van uit gaan dat het jaarlijkse aantal geslaagden gedurende de rest van de prognoseperiode op het niveau van 1989 zal blijven liggen, wordt vervolgens een prognose van de gediplomeerde uitstroom voor de gehele periode 1989-1994 verkregen.

Naar alle waarschijnlijkheid zijn de arbeidsmarktkansen voor de oudere deelnemers aan scholingsmaatregelen geringer dan voor jongere deelnemers. Derhalve wordt hiervoor een correctie op de prognose van de gediplomeerde uitstroom van de ARBVO-opleidingen aangebracht. Daarbij wordt aangenomen dat alleen geslaagden die jonger zijn dan 25 jaar tot de potentiële arbeidsmarktinstroom behoren. De leeftijdscorrectiefactor wordt berekend op basis van de leeftijdsverdeling van de deelnemers aan de ARBVO-scholingsmaatregelen in 1989. Van de gecorrigeerde verwachte uitstroom wordt verondersteld dat zij geen andere onderwijsdiploma's bezitten. Zij worden dus in mindering gebracht op de verwachte arbeidsmarktinstroom van schoolverlaters die alleen het basisonderwijs succesvol hebben doorlopen. 


\section{BESLUIT}

In dit werkdocument is een beschrijving gegeven van de methodiek die wordt gebruikt om voor de in het ROA-informatiesysteem onderwijs-arbeidsmarkt onderscheiden opleidingstypen een raming te maken van het aantal schoolverlaters dat op middellange termijn zal uitstromen naar de arbeidsmarkt. De uitkomsten van deze prognose zijn opgenomen in de derde volledige versie van het informatiesysteem. Daarin worden 54 opleidingstypen onderscheiden, waaronder 5 restcategorieën. De prognoses hebben betrekking op de periode 1989-1994.

De methodiek die voor de raming van het toekomstig aanbod van schoolverlaters op de arbeidsmarkt wordt gehanteerd, steunt in belangrijke mate op externe prognoses. Het prognosemodel wordt gekenmerkt door een stapsgewijze opbouw. In de eerste stap wordt een prognose gemaakt van de uitstroom uit het regulier voltijdonderwijs. Vervolgens vindt in de tweede stap een correctie van deze prognose plaats (in de vorm van een herverdeling) op basis van een raming van de toekomstige gediplomeerde uitstroom uit het regulier deeltijdonderwijs, enkele niet-reguliere opleidingen en de beroepsgerichte volwasseneneducatie.

Een sterk punt van de ROA-prognose van de toekomstige arbeidsmarktinstroom van schoolverlaters is dat er ook getracht wordt rekening te houden met opleidingskwalificaties die in het deeltijdonderwijs en het niet-regulier voltijdonderwijs kunnen worden verworven. Echter, methodisch gezien is dit onderdeel van de aanbodprognose weinig bevredigend, doordat vanwege het ontbreken van allerhande informatie veel veronderstellingen moeten worden gemaakt. Meestal zijn dergelijke veronderstellingen gebaseerd op verhoudingsgetallen e.d., zoals die in het regulier voltijdonderwijs worden aangetroffen. Om te voorkomen dat de op dergelijke aannames gebaseerde prognoses tot grote vertekeningen zouden leiden, is ook een zeer conservatieve schatting gemaakt van de veranderingen die optreden in het kwalificatieprofiel als gevolg van de beroepsgerichte volwasseneneducatie, omdat met name bij deze opleidingen vaak moeilijk is aan te geven in hoeverre een substantiële verandering in het opleidingsprofiel wordt bewerkstelligd. Al met al kan worden geconcludeerd dat het zeer waardevol zou zijn deze onderdelen van de aanbodprognoses verder te verbeteren. Veel zal daarbij afhangen van het kunnen achterhalen c.q. beschikbaar komen van meer en beter datamateriaal. Daarbij is er met name behoefte aan opleidingsdata die rechtstreeks koppelbaar zijn aan de Standaard Onderwijsindeling van het CBS. Verder dient het gebrek aan gegevens over de vooropleiding van de gediplomeerde uitstromers uit het deeltijdonderwijs en het niet-regulier voltijdonderwijs te worden opgevuld.

Wellicht zal in een deel van de behoefte aan meer en betere data kunnen worden voorzien door gegevens die voortkomen uit de Registratie van de Uitstroom en de Bestemming van Schoolverlaters (RUBS) en de door het ROA ontwikkelde HBO-Monitor. Deze grootschalige schoolverlatersenquêtes hebben betrekking op respectievelijk het voortgezet onderwijs (AVO, LBO en MBO) en het hoger beroepsonderwijs. Er zou onder andere moeten worden nagegaan in hoeverre aan de RUBS-enquête en de HBO-Monitor gegevens kunnen worden ontleend over de mate waarin schoolverlaters zich beschikbaar stellen voor de arbeidsmarkt en de ontwikkelingen die daarin 
optreden. Daarbij gaat het niet alleen om meer recente en meer gedetailleerde informatie dan uit de onderwijsmatrix van het CBS kan worden gehaald, maar ook om de mogelijkheid trendmatige ontwikkelingen in dit patroon te kunnen traceren, wanneer er over een aantal waarnemingsjaren informatie beschikbaar is uit deze schoolverlatersenquêtes. Daarnaast zou de bruikbaarheid van de gegevens over de vooropleiding van de schoolverlaters moeten worden onderzocht.

Van groot belang voor de ROA-prognose van de arbeidsmarktinstroom van schoolverlaters is vanzelfsprekend ook de beschikbaarheid van de nieuwe leerlingen- en studentenraming van het Ministerie van Onderwijs en Wetenschappen, de zogenaamde Referentieraming. De overgang naar het gebruik van de opvolger van de SKILL-raming, maakt het noodzakelijk om bij de ontwikkeling van een volgende versie van het ROA-informatiesysteem enkele ingrijpende veranderingen in de prognosemethodiek met betrekking tot de arbeidsmarktinstroom van schoolverlaters door te voeren. Daarvoor zijn een aantal redenen. Ten eerste zijn in de Referentieraming niet alleen prognoses opgesteld voor het regulier voltijdonderwijs, maar ook voor het deeltijd-AVO (MAVO, HAVO en VWO), het deeltijd-MEAO en het deeltijd-HBO (HTNO, HGZO, HEO, HSAO, HKO en HPO). Ten tweede is voor het $\mathrm{HBO}$ een afzonderlijke verdeelraming gemaakt, waarbij de prognoses naar een lager aggregatieniveau zijn uitgesplitst, maar wel op de oorspronkelijke ramingen zijn genormeerd. Ten derde bevat de Referentieraming ook prognoses voor het voltijd-КМBO. Ten vierde zijn buiten het hoofdmodel van de Referentieraming prognoses opgesteld van de aantallen leerlingen in het deeltijd-beroepsonderwijs (MTO, MLO, MDGO en het Leerlingwezen. Aangezien in de ROA-prognoses met alle genoemde onderwijssoorten rekening wordt gehouden, zal moeten worden nagegaan op welke wijze de huidige prognosemethodiek moet worden aangepast om daar waar mogelijk gebruik te maken van de prognoses uit de Referentieraming. Wellicht dat hiermee tevens een deel van de problematiek met betrekking tot de verdere ontwikkeling van de ramingsmethodiek ten aanzien van de toekomstige uitstroom uit het regulier deeltijdonderwijs en het beroepsgerichte volwassenenonderwijs kan worden opgelost.

Ook op enkele andere punten zou wellicht aan een verbetering van de prognosemethodiek kunnen worden gewerkt. Hierbij zou bijvoorveeld kunnen worden gedacht aan een onderzoek naar de inpassing van externe prognoses met betrekking tot het in-service-onderwijs. Tot slot zou moeten worden nagegaan in hoeverre in de prognoses rekening moet worden gehouden met de geslaagden voor staatsexamens. 


\section{LITERATUUR}

Beekman, Th.B.J., R.J.P. Dekker, A. de Grip, J.A.M. Heijke (1989), Een verklaring van de opleidingenstructuur van beroepen, ROA-W-1989/3, Maastricht.

Beekman, Th.B.J., R.J.P. Dekker, A. de Grip, J.A.M. Heijke (1991), An Explanation of the Educational Structure of Occupations, in: Labour, vol. 5, no. 3, pp. 151-163.

Berendsen, H., A. de Grip, M.H. Wieling, E.J.T.A. Willems (1992), Regionale arbeidsmarktinformatie naar opleiding en beroep, ROA-R-1992/2, Maastricht.

Bisschop, C.B., W.J. Nijhof, A.M.L. van Wieringen (1988), Poly-onderwijs zakboekje, Koninklijke PBNA, Arnhem.

Bronneman-Helmers, R. (1988), Samenhang rond volwasseneneducatie; deel I: jeugdonderwijs en vo/wasseneneducatie, Sociaal en Cultureel Planbureau, Rijswijk.

Centraal Bureau voor de Statistiek (1988), Bedrijfsopleidingen in Nederland 1986, 's Gravenhage.

Centraal Bureau voor de Statistiek (1989), Studenten bij de Open Universiteit, 1 november 1988, Mededelingen CBS, no. 7889, Voorburg/Heerlen.

Centraal Bureau voor de Statistiek (1990a), Statistiek van het hoger beroepsonderwijs 1987/'88 en 1988/'89; instellingen en studenten, 's Gravenhage.

Centraal Bureau voor de Statistiek (1990b), Statistiek van het lager beroepsonderwijs 1989/'90; scholen, leerlingen en examens, 's Gravenhage.

Centraal Bureau voor de Statistiek (1990c), Statistiek van het middelbaar beroepsonderwijs 1989/'90; scholen en leerlingen, 's Gravenhage.

Centraal Bureau voor de Statistiek (1990d), Statistiek van het vwo, havo en mavo 1989/'90; scholen, leerlingen en examens, 's Gravenhage.

Centraal Bureau voor de Statistiek (1990e), Statistisch jaarboek 1990, 's Gravenhage.

Centraal Bureau voor de Statistiek (1990f), Volwasseneneducatie; beroepsbegeleidend onderwijs en vormingswerk/cursorisch ondernemersonderwijs 1988/'89, 's Gravenhage.

Centraal Bureau voor de Statistiek (1991a), Volwasseneneducatie; particulier onderwijs, 1989, 's Gravenhage. 
Centraal Bureau voor de Statistiek (1991b), Volwasseneneducatie, statistisch overzicht 1989, 's Gravenhage.

Dekker, R.J.P., A. de Grip, J.A.M. Heijke (1988), Een verklaring van de beroepenstructuur van bedrijfstakken, ROA-W-1988/2, Maastricht.

Dekker, R.J.P., A. de Grip, J.A.M. Heijke (1990), An Explanation of the Occupational Structure of Sectors of Industry, in: Labour, vol. 4, no. 3, pp. 3-31.

Ganga, V. (1992), Deelname, uitval en rendement van het leerlingwezen, Ministerie van Onderwijs en Wetenschappen, Directie Beroepsonderwijs en Volwasseneneducatie, Den Haag.

Kuhry, B. (1986), The impact of socio-economic factors on the demand for education, Centraal Planbureau, Research Memorandum, no. 21, 's-Gravenhage.

Manders (1989), Raming arbeidsaanbod 1985-2000, Centraal Planbureau, interne notitie II/35, 's Gravenhage.

Mattila, J.P. (1982), Determinants of male school enrolments; a time series analysis, in: Review of Economics and Statistics, vol. 64, 2, pp. 242-250.

Ministerie van Onderwijs en Wetenschappen (1990), SKILL 1990-II, interne notitie, Zoetermeer.

Ministerie van Onderwijs en Wetenschappen (1991), Referentieraming 1991, 's Gravenhage.

Ministerie van Sociale Zaken en Werkgelegenheid (1988), Schoolverlatersbrief 1988, Rijswijk.

Nationaal Ziekenhuisinstituut (1987), De arbeidsmarkt voor verpleegkundigen en ziekenverzorgenden; proefproject in het noorden van het land, Utrecht/Oudemolen.

Peeters, H.M.M. (1990), An Explanation of the Occupational and Educational Structure by Means of Multinomial Logit, ROA-W-1990/4E, Maastricht.

Researchcentrum voor Onderwijs en Arbeidsmarkt (1992a), De arbeidsmarkt naar opleiding en beroep tot 1994, ROA-R-1992/1, Maastricht.

Researchcentrum voor Onderwijs en Arbeidsmarkt (1992b), De arbeidsmarkt naar opleiding en beroep tot 1994; Statistische bijlage, ROA-R-1992/1B, Maastricht.

Taakgroep Studentenramingen (1990), HO-raming 1990; deel I: WORSA, Zoetermeer.

Taakgroep Studentenramingen (1990), HO-raming 1990; deel II: RHOBOS, Zoetermeer. 
$-47-$

Whitfield, K., R.A. Wilson (1991), Forecasting the educational participation rate of 16-year olds in England and Wales; a socio-economic approach, in: International Journal of Forecasting, vol. 7, pp. 65-76.

Willems, E.J.T.A., A. de Grip (1990), Vervangingsvraagprognoses naar beroep en opleiding, ROA-W-1990/7, Maastricht. 


\section{BIJLAGE 1: ROA-OPLEIDINGSTYPEN}

$\begin{array}{ll}\text { ROA- omschrijving } & \text { SOI- } \\ \text { code } & \text { code }\end{array}$

\begin{tabular}{|c|c|}
\hline Basisonderwijs & $000-211$ \\
\hline MAVO en onderbouw HAVO/VWO & 301 \\
\hline LBO Agrarisch & $321-329$ \\
\hline LBO Technisch & $331-339$ \\
\hline LBO Haven \& Vervoer & $341-349$ \\
\hline LBO Economisch-Administratief & $361-369$ \\
\hline LBO Verzorgend & $381-389$ \\
\hline LBO Beveiliging \& Bewaking & $391-394$ \\
\hline LBO Rest & overig $3 .$. \\
\hline Bovenbouw HAVO/VWO & 401 \\
\hline MBO Agrarisch & $421-429$ \\
\hline MBO Technisch Laboratorium & 431 \\
\hline MBO Technisch & $436-439$ \\
\hline MBO Haven \& Vervoer & $441-449$ \\
\hline MBO Medisch Laboratorium & 452 \\
\hline MBO Verpleging \& Ziekenverzorging & 451,454 \\
\hline MBO Economisch \& Administratief & $453,461,462,464$ \\
\hline MBO Bestuurlijk & 466 \\
\hline MBO Sociaal-Cultureel & 471 \\
\hline MBO Verzorging & $481,484,486$ \\
\hline MBO Horeca \& Kappers & 483 \\
\hline MBO Politie \& Defensie & $491-494$ \\
\hline MBO Rest & overig $4 .$. \\
\hline HBO Onderwijs & 506 \\
\hline HBO Tolk \& Vertaler & 511 \\
\hline HBO Theologisch & 516 \\
\hline HBO Agrarisch & $521-529$ \\
\hline HBO Technisch Laboratorium & 531 \\
\hline HBO Technisch & $536-539$ \\
\hline HBO Haven \& Vervoer & $541-549$ \\
\hline HBO Medisch Laboratorium & 552 \\
\hline HBO Verpleging \& Paramedisch & 551,554 \\
\hline HBO Economisch-Administratief & 561 \\
\hline HBO Technische Bedrijfskunde & 562 \\
\hline HBO Bestuurlijk & 566 \\
\hline HBO Sociaal-Cultureel & 571 \\
\hline HBO Horeca & 583 \\
\hline HBO Kunst & 586 \\
\hline HBO Politie \& Defensie & $591-594$ \\
\hline
\end{tabular}


$-49-$

$\begin{array}{lll}40 & \text { HBO Rest } & \text { overig } 5 . . \\ 41 & \text { WO Onderwijs } & 606 \\ 42 & \text { WO Humaniora } & 611 \\ 43 & \text { WO Theologisch } & 616 \\ 44 & \text { WO Agrarisch } & 621-623,629 \\ 45 & \text { WO Wis-/Natuurkunde } & 631 \\ 46 & \text { WO Technisch } & 636-639 \\ 47 & \text { WO Dier-/Genees-/Tandheelkunde } & 651 \\ 48 & \text { WO Farmacie } & 652 \\ 49 & \text { WO Econom(etr)ie \& Bedrijfskunde } & 661,662 \\ 50 & \text { WO Rechten \& Bestuurskunde } & 666 \\ 51 & \text { WO Sociaal-Cultureel } & 671 \\ 52 & \text { WO Kunst } & 686 \\ 53 & \text { WO Rest } & \text { overig } 6 . . \\ 54 & \text { overige codes } & \end{array}$




\section{BIJLAGE 2: PROGNOSERESULTATEN 1989-1994}

Verwachte arbeidsmarktinstroom van schoolverlaters $1989-1994^{31}$

ROA- opleidingstype
code

\section{BASISONDERWIJS}

MAVO, LBO

$\begin{array}{ll}2 & \text { MAVO en onderbouw HAVO/VWO } \\ 3 & \text { LBO Agrarisch } \\ 4 & \text { LBO Technisch } \\ 5 & \text { LBO Haven \& Vervoer } \\ 6 & \text { LBO Economisch-Administratief } \\ 7 & \text { LBO Verzorgend } \\ 8 & \text { LBO Beveiliging \& Bewaking }\end{array}$

$\begin{array}{rrl}40.700 & 8 & \text { erg laag } \\ 12.800 & 12 & \text { laag } \\ 70.200 & 13 & \text { laag } \\ 1.200 & 4 & \text { erg laag } \\ 19.300 & 11 & \text { laag } \\ 30.800 & 11 & \text { laag } \\ 1.600 & 27 & \text { hoog }\end{array}$

HAVONWO, MBO

$\begin{array}{ll}10 & \text { Bovenbouw HAVO/VWO } \\ 11 & \text { MBO Agrarisch } \\ 12 & \text { MBO Technisch Laboratorium } \\ 13 & \text { MBO Technisch } \\ 14 & \text { MBO Haven \& Vervoer } \\ 15 & \text { MBO Medisch Laboratorium } \\ 16 & \text { MBO Verpleging \& Ziekenverzorging } \\ 17 & \text { MBO Economisch \& Administratief } \\ 18 & \text { MBO Bestuurlijk } \\ 19 & \text { MBO Sociaal-Cultureel } \\ 20 & \text { MBO Verzorgend } \\ 21 & \text { MBO Horeca \& Kappers } \\ 22 & \text { MBO Politie \& Defensie }\end{array}$

$\begin{array}{rrl}96.100 & 28 & \text { hoog } \\ 28.400 & 24 & \text { gemiddeld } \\ 1.200 & 8 & \text { erg laag } \\ 155.200 & 23 & \text { gemiddeld } \\ 7.600 & 17 & \text { gemiddeld } \\ 1.700 & 7 & \text { erg laag } \\ 50.100 & 27 & \text { hoog } \\ 135.300 & 19 & \text { gemiddeld } \\ 3.500 & 8 & \text { erg laag } \\ 23.800 & 57 & \text { erg hoog } \\ 65.400 & 27 & \text { hoog } \\ 8.600 & 16 & \text { gemiddeld } \\ 17.200 & 18 & \text { gemiddeld }\end{array}$

HBO

$\begin{array}{ll}24 & \text { HBO Onderwijs } \\ 25 & \text { HBO Tolk \& Vertaler } \\ 26 & \text { HBO Theologisch } \\ 27 & \text { HBO Agrarisch }\end{array}$

$\begin{array}{rll}38.200 & 14 & \text { laag } \\ 600 & 10 & \text { laag } \\ 700 & 15 & \text { laag } \\ 7.500 & 50 & \text { erg hoog }\end{array}$

31. Absolute aantallen en als percentage van het aantal werkenden in 1989. 
Verwachte arbeidsmarktinstroom van schoolverlaters 1989-1994 (vervolg)

\begin{tabular}{|c|c|c|c|c|}
\hline $\begin{array}{l}\text { ROA- } \\
\text { code }\end{array}$ & opleidingstype & aantal & $\%$ & typering \\
\hline 28 & HBO Technisch Laboratorium & 4.300 & 16 & gemiddeld \\
\hline 29 & HBO Technisch & 30.200 & 25 & gemiddeld \\
\hline 30 & HBO Haven \& Vervoer & 2.200 & 8 & erg laag \\
\hline 31 & HBO Medisch Laboratorium & 2.400 & 13 & laag \\
\hline 32 & HBO Verpleging \& Paramedisch & 31.700 & 41 & hoog \\
\hline 33 & HBO Economisch-Administratief & 28.600 & 18 & gemiddeld \\
\hline 34 & HBO Technische Bedrijfskunde & 4.000 & 44 & hoog \\
\hline 35 & HBO Bestuurlijk & 2.900 & 13 & laag \\
\hline 36 & HBO Sociaal-Cultureel & 23.300 & 23 & gemiddeld \\
\hline 38 & HBO Kunst & 9.800 & 27 & hoog \\
\hline \multirow[t]{2}{*}{39} & HBO Politie \& Defensie & 1.800 & 16 & gemiddeld \\
\hline & wo & & & \\
\hline 41 & wo Onderwijs & 5.000 & 23 & gemiddeld \\
\hline 42 & Wo Humaniora & 18.200 & 52 & erg hoog \\
\hline 43 & wo Theologisch & 900 & 10 & laag \\
\hline 44 & wo Agrarisch & 4.200 & 47 & hoog \\
\hline 45 & WO Wis-/Natuurkunde & 8.200 & 20 & gemiddeld \\
\hline 46 & wo Technisch & 18.800 & 31 & hoog \\
\hline 47 & WO Dier-/Genees-/Tandheelkunde & 9.500 & 19 & gemiddeld \\
\hline 49 & WO Econom(etr)ie \& Bedrijfskunde & 26.100 & 52 & erg hoog \\
\hline 50 & WO Rechten \& Bestuurskunde & 24.700 & 53 & erg hoog \\
\hline 51 & WO Sociaal-Cultureel & 28.400 & 38 & hoog \\
\hline 52 & Wo Kunst & 3.400 & 49 & erg hoog \\
\hline
\end{tabular}

Bron: ROA 